\title{
A Proposed Model for Measuring the Performance of Smart Cities in Egypt
}

\author{
Hesham T. Eissa ${ }^{1^{*}}$ and Ahmed N. A. El-Nahas ${ }^{2}$

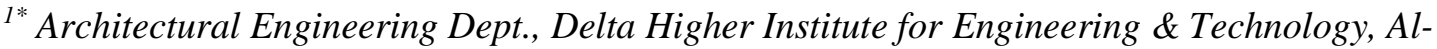 \\ Mansoura, Egypt (Corresponding author: hesheissa@gmail.com) \\ ${ }^{2}$ PhD Candidate, Department of Architecture, Shoubra Faculty of Engineering, Benha University, \\ Cairo, Egypt
}

\begin{abstract}
Smart communities/cities are technology-based urban communities, those measures supporting a city to improve its social, economic, and environmental conditions and provide a better life for the city's residents with their participation in the planning of city projects. Many classifications indices, reference frameworks, forums, and assessment centers have developed; such classifications indices and centers govern and measure the performance of existing traditional and smart communities/cities and also work as guide lines to create new Smart communities/cities or transforming existing traditional cities into smart ones. The criteria of such new communities vary from one category to another and lack or omit some dimensions to interact and merge with the surrounding urban environment, especially the already existing communities. That would have a negative impact not only on smart communities but also on the entire community as the new smart communities that would appear secluded form neighboring urban environment. Therefore, the need to reduce these negative influences of existing communities and gradually transform them into smart communities is important to enhance the interaction efficiency. Therefore, the necessity of activating the existing cities and transforming those into smart ones in Egypt is essential. Therefore, the research proposed a comprehensive model to measure the performance of smart cities in Egypt that derive the dimensions, standards and indicators governing the global rankings and add what is missing from these classifications achieving a reference framework or mechanism to serve as a new classification helps to assess performance in response to the requirements of smart communities.
\end{abstract}

Keywords: smart city; key performance indicators (KPIs); smart environment; cultural dimension.

\section{Introduction}

The information economy, with the effects of the digital revolution and the new global economy, has had a significant impact on changing the role of cities and societies. The term "smart communities/cities" is used to refer to technology-based urban communities, a comprehensive term for developmental means aimed at supporting a city to improve its social, economic, and environmental conditions. Furthermore, to provide a better life for the city's residents, also considering the idea of citizen participation in the planning of city projects. In order to preserve and sustain these communities and to highlight their role as smart communities, many classifications indices, reference frameworks, forums, and assessment centers have developed Such as: CSCI, 1995, Komninos, 2009-2011, ICF, 2011 - ISO / TS 37151, 2015, and many more that employ dimensions, criteria, and indicators (KPIs). Such classifications indices and centers not only govern or measure the performance of existing traditional and smart communities/cities such as but also work as guide lines for creating new Smart communities/cities or transforming existing traditional cities into smart ones.

The research problem is that the criteria of such new communities vary from one category to another and lack or omit some dimensions to interact and merge with the surrounding urban environment, especially the already existing communities that have not yet taken their chance towards such improvement. That would have a negative impact not only on smart communities but also on the entire community as the new smart communities would appear secluded form neighboring urban environment, Nevertheless, interaction with existing communities is imperative, which emphasizes the need to reduce these negative influences of existing communities and gradually transform them into smart communities to enhance the interaction efficiency . 


\section{Hesham T. Eissa and Ahmed N. A. El-Nahas "A Proposed Model for Measuring the Performance of Smart Cities in Egypt”}

On the other hand, there is no local / national mechanism in Egypt to measure the performance of smart or traditional communities, or reference frameworks for adopting the policy of establishing smart cities and transforming the existing traditional ones into smart cities. In addition to the lack of global standards for smart cities as some dimensions, standards and indicators are absent that represent negative internal dimensions in smart communities themselves. For example, the dimensions of cultural identity, civilization or social features, visual configuration, architectural iconography, symbolic value, unique personality, harmony with the urban environment, etc.

\section{Research Significance, Aim, and Methodology} Egypt is one of the countries possesses the ingredients qualified to adopt the policy of establishing smart societies / cities, especially the environment that stimulates this type of cities, instead of gradual depletion of such environment, which confirms the inevitability of activating the existing cities.

The Research Aim: Therefore, the research aims to extract and derive the dimensions, standards and governing indicators from the global classifications, to add the missing culture identity dimension to classifications; accordingly reaching a reference framework or mechanism for measuring the performance of smart and traditional societies / cities alike. That would serve as a new classification that helps to evaluate performance in a way that responds to the requirements of smart societies.

The Research Methodology: The methodology is following the deductive methodology to identify and derive the standards governing smart communities according to their approach regarding performance, order, services and the ability to learn and link with the standards of green and sustainable societies. Then an analytical approach would be adopted to drive new classification based on indicators (KPIs) to measure the performance of these smart communities / cities as well as traditional communities to increase their effectiveness towards the gradual transformation to smart communities.

\section{The Concept of Smart Community/City}

There is no single definition of what makes a community "smart", "flexible", "viable" or "sustainable," and no one understands community as its citizens do, nor a clear definition of smart communities / cities. Other terms have been appeared to describe the "Smart" such as: "wired", "broadband", "digital", "networked", "smart community network", "community informatics", "smart" and "green" were used Interchangeably among researchers, but all mean communities that are making "a conscious effort to understand the world that is closely related" [1].

Although there are some differences in the way the above terms are used by different researchers, all definitions have three main common aspects:

- Communications means (network infrastructure / technology / ICT)

- Communication between different action authorities

- Target (public participation or others)

For example, the Canadian Federal Government (CFG) defines SMART as communities where local leaders and stakeholders, through the use of electronic networks and the Internet, forge alliances and partnerships for innovation and extracting new economic resources [2]. Social value lies in this definition, focusing on network deployment (transport, ICT), as well as investments in human and social capitals in support of sustainable community objectives and life quality, through social participation as well as user technologies and smart community applications.

Smart City is "a city that makes a conscious effort to use ICTs in a creative way to support a more inclusive, diverse and sustainable urban environment". This concept adopted by California Institute of Smart Communities [3] focusing on the importance of social and environmental capital in urban development; which means communities that teach their citizens to learn, adapt and innovate. Also focuses strongly on social inclusion and participation in community affairs and decision-making processes to achieve social and environmental goals.

\subsection{The concept of "smart" criteria S.M.A.R.T.:} The expression "smart" SMART is the abbreviation of the letters $\mathrm{S}$ and $\mathrm{M}$ usually means specific and measurable, the most common that the remaining letters $\mathrm{A}, \mathrm{R}$ and $\mathrm{T}$ refer to achievable, relevant and time-bound. Doran and George T. have identified the standards of S.MA.R.T. "As a method of writing management objectives, management review" 2008 as follows: [4]

- Specific: Target specific area for improvement.

- Measurable: or suggest at least an indicator of progress.

- Achievable, Assignable or Attainable: Select who will do this.

- Relevant or Realistic: results that can be realistically achieved given the resources available.

- Time-bound or Time related: Determine when the result can be achieved

Criteria are illustrated and explained in Table (1) 
Table 1- The most common meanings of SMART standards and their alternatives [5]

\begin{tabular}{|c|c|c|}
\hline Letter & $\begin{array}{c}\text { Most } \\
\text { common }\end{array}$ & Alternative \\
\hline $\mathrm{S}$ & Specific & Strategic and specific \\
\hline M & Measurable & $\begin{array}{l}\text { Motivating (Source: } \\
\text { One Minute Manager) }\end{array}$ \\
\hline A & Achievable & $\begin{array}{l}\text { Agreed, attainable, } \\
\text { action-oriented, } \\
\text { ambitious, aligned } \\
\text { with corporate goals, } \\
\text { (agreed, attainable and } \\
\text { achievable) }\end{array}$ \\
\hline $\mathrm{R}$ & Relevant & $\begin{array}{l}\text { Realistic, resourced, } \\
\text { reasonable, (realistic } \\
\text { and resourced), } \\
\text { results-based }\end{array}$ \\
\hline $\mathrm{T}$ & Time-bound & $\begin{array}{l}\text { Trackable (Source: } \\
\text { One Minute Manager), } \\
\text { Time-based, time } \\
\text { limited, time/cost } \\
\text { limited, timely, time- } \\
\text { sensitive, timeframe, } \\
\text { Testable }\end{array}$ \\
\hline
\end{tabular}

Doran and George T. on SMART standards said:

"Notice that these criteria don't say that all objectives must be quantified on all levels of management. In certain situations it is not realistic to attempt quantification, particularly in staff middle management positions. Practicing managers and corporations can lose the benefit of a more abstract objective in order to gain quantification. It is the combination of the objective and its action plan that is really important. Therefore, serious management should focus on these twins and not just the objective." [4].

\subsection{Dimensions of Smart City Development:}

Regarding the economy, a "smart" city can be a city that hosts a "smart" industry (i.e., an industry that is either a producer or user of innovative ICT), or a city that develops high-ICT-based business parks in its territory. Also smart term is used to describe a city with a high "intelligent" population, i.e. highly educated local human resources [3]. Smart city is a city relies heavily on government-citizen interaction on ICTs, or a city that shows strong ICT participation in decision making (Electronic Democracy) [6], moreover, may refer to a city taking advantage of modern ICT in urban processes in order to improve the quality of life of its population (such as 'smart' transportation systems to support urban traffic management), and finally, the term uses To describe a city that uses ICT to improve services in several areas, for example: Security/safety, health, green development, or sustainable energy consumption [7]. In the European Smart Cities Project (Vienna University of Technology), six dimensions of "intelligence" were identified, indicating: economy, local citizens, governance, mobility, environment and way of living, shown in Figure (1), along with a set of indicative issues rose within each category [3].

How to turn cities into smart cities :

- Organize a fair distribution of resources and responsibilities in various areas of government and strengthen local governments to enable them to act as autonomous institutions that deliver services effectively and efficiently

- Provide an integrated and transparent governance framework as well as clear directions of authority and accountability to achieve the objectives of "good urban governance."

- Facilitate and promote the principle of inclusiveness, civic participation and the active involvement of civil community in city administration.

- Enable cities to work towards operation and maintenance to provide planned and integrated infrastructure.

- Develop partnerships with the public, private and other sectors to enhance providing and delivering service.

- Extend the scope of information technology and egovernment to all aspects of city management in order to provide services effectively, efficiently and quickly [8].

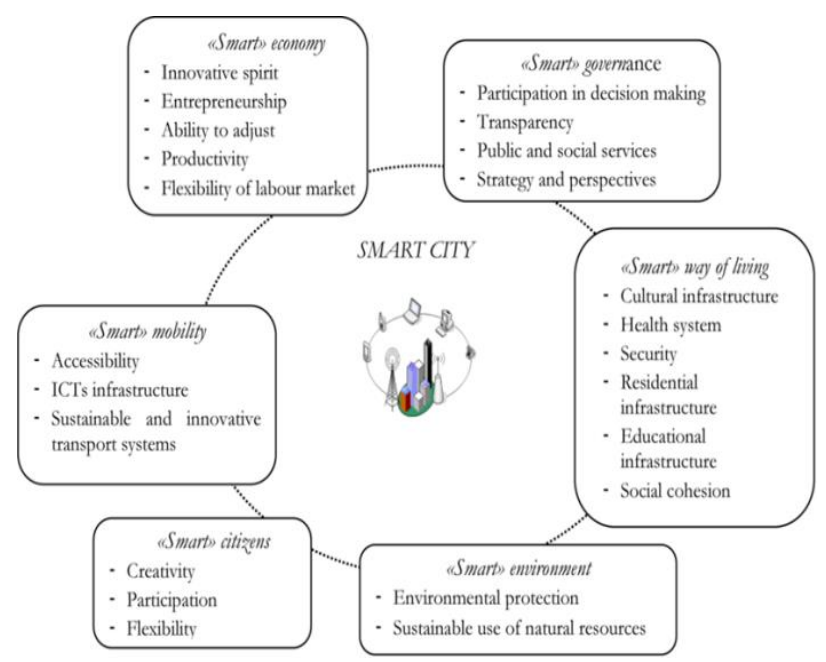

Figure 1- Dimensions of Smart City Development [9] (Adapted by Tsarchopoulos, 2006) 


\section{Hesham T. Eissa and Ahmed N. A. El-Nahas "A Proposed Model for Measuring the Performance of Smart Cities in Egypt”}

\section{Global Classifications}

(Frameworks and models used to measure the performance of smart communities/cities)

The Canadian Smart Cities Institute (CSCI), organized the SMART95, the first smart city conference, held in Toronto in September 1995. Then moved from Canada to New York City in the late 1990s in what is called the Smart Community Forum as a non-profit global center; afterwards called "smart cities" since the mid-nineties. Smart Cities / Communities well known as SMART21 where 7 smart clusters/cities are chosen on October each year among the best 21 smart cities from all over the world, for measurement purposes, called TOP7. Then in January, a typical example out of TOP7 is chosen annually to represent the "Smart Community of the Year" which serves as the best reference community and most recently the ECV Summit in Columbus, Ohio, 2016 [10].

Cities are expected to benefit from the use of these performance indicators, which take into account the elements of a sustainable smart city that is heavily ICT-based and provide a documented measure of progress in the transition to sustainable smart cities, where they have joined the United Nations Smart Sustainable Initiative (U4SSC) launched by ITU. International Telecommunication Union and the United Nations Economic Commission for Europe in Rome on 18 May 2016.

There are many models to measure the performance of smart cities even they might vary in measurement indicators for which a relative weight is assigned for quantitative evaluation. Those models frames are:

\subsection{City Keys Smart Cities Performance Framework}

The City Keys framework contains five basic dimensions; varying relatively in weights between $13 \%$ and $27 \%$, and distributed to each dimension according to the performance measurement indicators shown in Table (2) [11]. Based on the study of indicators from 43 existing indicators, a set of indicators was designed to evaluate the Smart City projects and the performance of Smart Cities for the City Keys framework; also new indicators were proposed to fill the gaps in existing frameworks, mostly related to specific characteristics of Smart City projects. [12]

The indicators were arranged in an expanded bottomup tripartite sustainability framework: People, planet and prosperity, finishing with specific smart city indicators, and sub-themes were identified that match key policy ambitions. This framework contains 92 project indicators and 73 city indicators, with all three-level sustainability indicators:

- Indicators for evaluating smart city projects that assess or evaluate individual projects, which indicate the difference that the project has made, or compare projects with each other.

Smart city indicators focus on monitoring the development of the city towards a smarter city "development over the years" and city indicators can be used to show the extent to which public policy objectives have been reached [13][14].

Table (2) - City Keys: Smart city indicators framework

\begin{tabular}{|c|c|c|c|c|c|c|c|c|c|}
\hline People & $\begin{array}{l}\overrightarrow{1} \\
\frac{0}{00} \\
\overrightarrow{0} \\
3\end{array}$ & Planet & 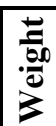 & Prosperity & 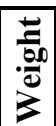 & Governance & 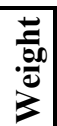 & Propagation & 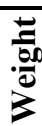 \\
\hline Health & 3 & $\begin{array}{l}\text { Energy \& } \\
\text { Mitigation }\end{array}$ & 7 & Employment & 2 & Organization & 6 & $\begin{array}{l}\text { Scalability \& } \\
\text { Replicability }\end{array}$ & 10 \\
\hline Safety & 4 & $\begin{array}{c}\text { Materials, } \\
\text { Water \& Land }\end{array}$ & \begin{tabular}{l|}
1 \\
0
\end{tabular} & Equity & 2 & $\begin{array}{l}\text { Community } \\
\text { Involvement }\end{array}$ & 5 & $\begin{array}{l}\text { Aspects of } \\
\text { success }\end{array}$ & 8 \\
\hline $\begin{array}{l}\text { Access to Other } \\
\text { Service }\end{array}$ & 8 & $\begin{array}{l}\text { Climate } \\
\text { Resilience }\end{array}$ & 1 & Green Economy & 3 & $\begin{array}{l}\text { Level -Multi } \\
\text { Governance }\end{array}$ & 2 & & \\
\hline Education & 3 & $\begin{array}{c}\text { Pollution \& } \\
\text { Waste }\end{array}$ & 4 & $\begin{array}{l}\text { Economic } \\
\text { Performance }\end{array}$ & 5 & & & & \\
\hline $\begin{array}{c}\text { \& Diversity } \\
\text { Social Cohesion }\end{array}$ & 3 & Ecosystem & 2 & Innovation & 5 & & & & \\
\hline $\begin{array}{c}\text { Quality of } \\
\text { Housing \& the } \\
\text { Built } \\
\text { Environment }\end{array}$ & 6 & & & $\begin{array}{l}\text { Attractiveness \& } \\
\text { Competitiveness }\end{array}$ & 1 & & & & \\
\hline & 27 & & 24 & & 18 & & 13 & & 18 \\
\hline \multicolumn{10}{|c|}{$100 \%$} \\
\hline
\end{tabular}




\section{Hesham T. Eissa and Ahmed N. A. El-Nahas "A Proposed Model for Measuring the Performance of Smart Cities in Egypt"}

\subsection{ICF Standards as Performance Indicators for Smart Communities:}

ICF - Intelligent Community Forum is a global network that connects hundreds of cities and regions on five continents to collaborate on economic development and exchange experiences and information that drive comprehensive prosperity, solving social problems and enriching the quality and quality of life in these communities :

- Broadband

- Knowledge Workforce

- Innovation

- Environmental Sustainability

- Advocacy

\subsection{International Standardization Organization} (ISO)

In October 2015 the ISO/TS 37151 issued for :

- Smart community infrastructures

- Principles and requirements for performance metrics.

International Standardization Organization (ISO) is a global federation of national standards bodies (ISO member bodies). International standards are usually prepared by ISO technical commissions, and each interested member body has the right to establish a technical committee to be represented in that committee, intergovernmental and non-governmental organizations also participate in liaison with the International Organization for Standardization (ISO) technical Standardization) [16].

The committee responsible for this document is ISO / TC 268, on sustainable development in communities, and $\mathrm{SC} 1$ on smart community infrastructures. Communities have different goals to achieve such as quality of life, economic growth, poverty reduction, pollution control, and alleviation of congestion. Community infrastructure such as energy, water, transport, waste control and ICTs are supportive of communities and their activities. Therefore, investment in such infrastructures enables communities to achieve internationally recognized societal goals (such as the UN Nations Millennium Development Goals (MDGs [17]) and promote propoor growth [18]. According to The Organization for Economic Co-operation and Development (OECD) Infrastructure 2030 accumulated to reach about 53 trillion US dollars during the period 2010/2030.

4.4 The de Bord Urban Framework (de Bord 2014, R. P. Dameri) for measuring smart city performance

The de Bord urban framework is a comprehensive framework that aims to link quantitative and qualitative indicators to a specific smart city strategy, select the most appropriate indicators, using urban statistical data already available in the municipality database, design a software program to achieve the smart city intelligence system, and determine the ability of this system to support more and expand Smart City Initiatives [19][20.[

The de Bord urban framework includes some key components: the regional dimension, technologies, products (services and infrastructure) and objectives, i.e. the life quality of citizens that respect the environment. This definition is able to describe the behavior of cities that trying to implement smart initiatives, even if they are not aware of the results and goals [21]. The definition of a Smart City describes this general framework as shown in Figure (2); it resembles the Smart Value Chain of Smart City [22].

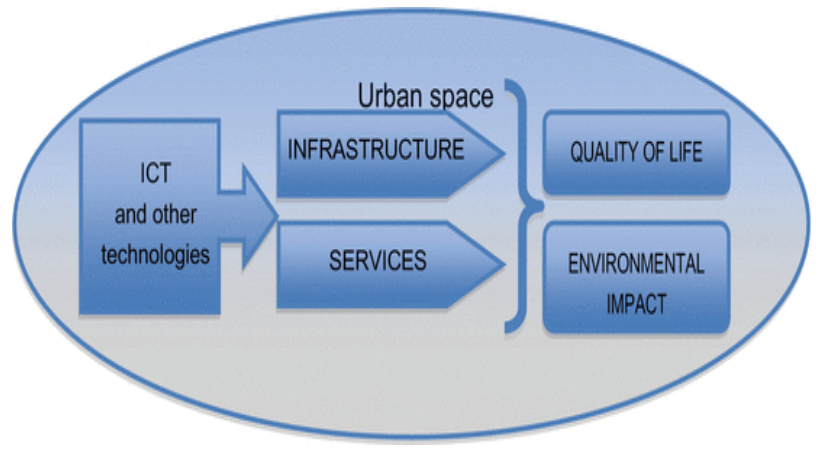

Figure 2- The general framework of the Smart City according to de Bord [17]

This classification reflects the OECD S-curve model to assess the impact of ICTs on people [22, 23]; Table (3) describes the multidimensional nature of the de Bord framework.

Table (3) - Brad framework for measuring smart cities performance

\begin{tabular}{|c|c|c|}
\hline $\begin{array}{l}\text { :Topic vision } \\
\text { Fields of } \\
\text { Interest }\end{array}$ & $\begin{array}{c}\text { Context :Vision } \\
\text { The } \\
\text { Stakeholders }\end{array}$ & $\begin{array}{c}\text { :Dynamic Vision } \\
\text { Output and } \\
\text { Outcome }\end{array}$ \\
\hline $\begin{array}{l}\text { - Smart Mobility } \\
\text { - Smart } \\
\text { Environment } \\
\text { - Smart People } \\
\text { - Smart Living } \\
\text { - Smart } \\
\text { - Governance } \\
\text { - Smart } \\
\text { Economy }\end{array}$ & $\begin{array}{l}\text { - Citizens } \\
\text { - Public } \\
\text { Administration } \\
\text { - Businesses }\end{array}$ & $\begin{array}{l}\text { - Used } \\
\text { Technology } \\
\text { - Services \& } \\
\text { Infrastructure } \\
\text { - Quality of Life } \\
\text { \& } \\
\text { Environmental } \\
\text { Impact }\end{array}$ \\
\hline
\end{tabular}


4.5 Framework of the Regional Science Center at the Vienna Technical University

A group of researchers at the Regional Science Center at the Technical University of Vienna identified 31 factors for assessing smart cities: (smart economy, smart people, smart government, smart mobility, smart environment, smart life), Eleven indicators were selected to analyze the performance of each factor [24]. The criteria were selected based on the concept of Smart City, which was used to reflect areas that use ICTs or cities with smart industries, including smart industries, as well as other industries using technologies in production processes, as well as cities seeking development of the education system.

This concept also includes the nature of relationship between government and citizens. Also, the use of modern technologies in daily life, not only limited to information and communication technologies, but also extends to modern transport technologies, in addition to many other concepts such as: security, safety, sustainability, and energy. Therefore, evaluation takes place through a hierarchical structure; each level expresses the level that precedes it. Each dimension is represented by a number of factors, and each factor is represented by a number of indicators.

4.6 Relative weights for smart city performance indicators in the framework of the University of Vienna:

The relative weight is divided equally among the six main dimensions, each of which constitutes $16.67 \%$ of the total relative weight. Table (4) shows the relative weight of each sub-criterion separately. The Vienna Technical University framework (as an integrated framework) was applied to measure the performance of seven cities: Bonn, Bristol, Stockholm, Rennes, Helsinki, Amsterdam and Copenhagen that is in several European countries: Germany, England, Sweden, France, Finland, Norway and Denmark according to the data of 2015. The evaluation of the six dimensions of the framework is evaluated for each dimension in the range from +2 to -2 as shown in Figure (3), the last column represents the overall average rating.

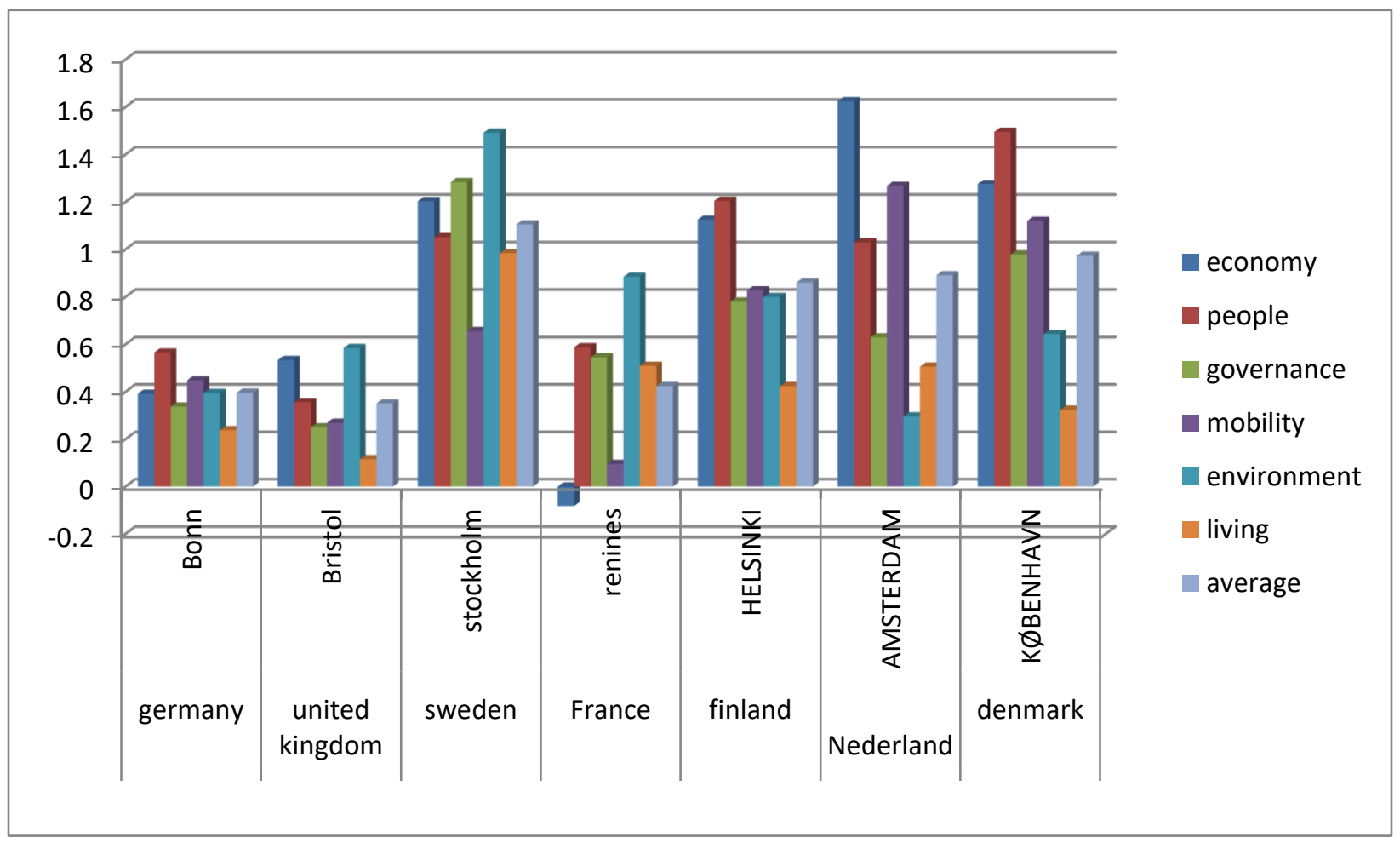

Figure 3- Application of the Vienna Technical University framework to measure the performance of smart cities on seven European cities [24] 
Table 4- Relative Weights of Smart City Performance Measurement Frameworks at the Technical University of Vienna [24]

\begin{tabular}{|c|c|c|}
\hline Criterion & Factors & Relative weight \\
\hline \multirow{7}{*}{ 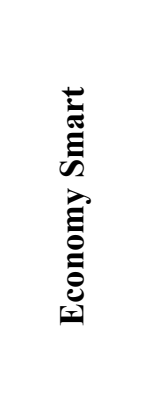 } & Innovative spirit & $2.78 \%$ \\
\hline & Entrepreneurship & $2.78 \%$ \\
\hline & Economic image $\&$ trademarks & $2.78 \%$ \\
\hline & Productivity & $2.78 \%$ \\
\hline & Flexibility of labor market & $2.78 \%$ \\
\hline & International embeddedness & $2.77 \%$ \\
\hline & Total & $16.67 \%$ \\
\hline \multirow{5}{*}{ 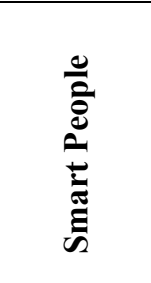 } & Level of qualification & $4.17 \%$ \\
\hline & learning Lifelong & $4.17 \%$ \\
\hline & Ethnic plurality & $4.17 \%$ \\
\hline & mindedness-Open & $4.16 \%$ \\
\hline & Total & $16.67 \%$ \\
\hline \multirow{4}{*}{ שֶ } & Participation public life & $5.55 \%$ \\
\hline & Public and social services & $5.55 \%$ \\
\hline & Transparent governance & $5.55 \%$ \\
\hline & Total & $16.65 \%$ \\
\hline \multirow{5}{*}{ } & Local accessibility & $4.17 \%$ \\
\hline & International accessibility & $4.17 \%$ \\
\hline & Infrastructure-Availability of IT & $4.17 \%$ \\
\hline & Sustainability of the transport system & $4.16 \%$ \\
\hline & Total & $16.67 \%$ \\
\hline \multirow{5}{*}{ 离 } & Environmental conditions & $4.175 \%$ \\
\hline & (Air quality (no pollution & $4.17 \%$ \\
\hline & Ecological awareness & $4.17 \%$ \\
\hline & Sustainable resource management & $4.16 \%$ \\
\hline & Total & $16.67 \%$ \\
\hline \multirow{8}{*}{ } & Cultural facilities & $2.38 \%$ \\
\hline & Health conditions & $2.38 \%$ \\
\hline & Individual security & $2.38 \%$ \\
\hline & Housing quality & $2.38 \%$ \\
\hline & Education facilities & $2.38 \%$ \\
\hline & Touristic attractiveness & $2.38 \%$ \\
\hline & Economic welfare & $2.39 \%$ \\
\hline & Total & $16.67 \%$ \\
\hline & Total & $100 \%$ \\
\hline
\end{tabular}





\section{Hesham T. Eissa and Ahmed N. A. El-Nahas "A Proposed Model for Measuring the Performance of Smart Cities in Egypt”}

5. GAP Analysis and Identification of Absent Dimensions and Indicators in the Performance Frameworks of Smart Communities

From the previous analysis of the global frameworks that measure the performance of smart cities, it is clear that the absence of the dimensions of civilization, urban and cultural identity makes smart cities repetitive in all environments, no matter how different these environments are regarding cultural and urban identity. This blurs the identity of people and civilizations throughout the ages as if smart cities have become templates regardless the social aspects. That leads to absence of urban formation, architectural iconography, uniqueness and mental and visual image of the city, in addition to the lack of frameworks for strategic planning and the economic base of the city and some elements of environmental sustainability.
Also, the measurements were based on dividing the relative weight equally on the main dimensions, although the number of indicators varies for each dimension, which makes the relative weight of the index is linked to the number of indicators of one dimension which lacks neutrality as the less the number of indicators the greater the relative weight of the index and the more the number of indicators the less weight of each index.

Therefore, there was an urgent need to add the culture and civilization dimension to confirm the identity of the smart city with the subsequent measurement indicators, in addition to proposing an accurate mathematical method to calculate the relative weights of the dimensions and indicators other than equal division to ensure the true measurement according to the priority and weight of each dimension and indicator (shown in Table: 5).

Table 5-Calculation of the relative weights of the dimensions (KPIs) indicators of the proposed model

\begin{tabular}{|c|c|c|c|c|c|c|c|c|c|}
\hline \multirow[b]{2}{*}{$\begin{array}{c}\text { Main } \\
\text { Dimensions }\end{array}$} & \multirow[b]{2}{*}{$\begin{array}{c}\text { Sub- } \\
\text { Dimensions }\end{array}$} & \multicolumn{3}{|c|}{ Examples of Smart Cities evaluation } & \multirow{2}{*}{$\begin{array}{c}\text { Average of } 3 \\
\text { Cities } \\
\text { Evaluation }\end{array}$} & \multirow{2}{*}{$\begin{array}{l}\text { Percentage } \\
\text { Dimension }\end{array}$} & \multirow{2}{*}{$\begin{array}{c}\text { Average of } 7 \\
\text { Cities } \\
\text { Evaluation } \\
\text { Figure (3) } \\
\end{array}$} & \multirow{2}{*}{\multicolumn{2}{|c|}{ Relative weigh }} \\
\hline & & $\begin{array}{l}\text { Singapore, } \\
\text { Singapore }\end{array}$ & $\begin{array}{r}\text { Trikala, } \\
\text { Greece }\end{array}$ & $\begin{array}{c}\text {,Barcelona } \\
\text { Spain }\end{array}$ & & & & & \\
\hline \multirow{3}{*}{ D1 } & D1-1 & 0.25 & 0.30 & 1.4 & 1.95 & 50.0 & \multirow{3}{*}{4.807} & \multirow{3}{*}{14.1} & 7.050 \\
\hline & D1-2 & -0.2 & 0.10 & -0.3 & -2.2 & 15.0 & & & 2.115 \\
\hline & D1-3 & -1.75 & -0.15 & 1.0 & -0.95 & 35.0 & & & 4.935 \\
\hline \multirow{4}{*}{ D2 } & D2-1 & -0.25 & 0.25 & 0.5 & 0.5 & 23.0 & \multirow{4}{*}{4.687} & \multirow{4}{*}{13.8} & 3.174 \\
\hline & D2-2 & -0.5 & 1.0 & 1.75 & 2.25 & 30.0 & & & 4.278 \\
\hline & D2-3 & -0.2 & 0.5 & 2.0 & 0.5 & 23.0 & & & 3.174 \\
\hline & D2-4 & -0.3 & 0.05 & 0.75 & 0.5 & 23.0 & & & 3.174 \\
\hline \multirow{4}{*}{ D3 } & D3-1 & -0.4 & -0.8 & -0.3 & -0.5 & 10.0 & \multirow{4}{*}{5.098} & \multirow{4}{*}{15.0} & 1.5 \\
\hline & D3-2 & 0.8 & 0.7 & -0.1 & 0.5 & 35.0 & & & 5.25 \\
\hline & D3-3 & 0.7 & 0.3 & 0.3 & 0.4 & 20.0 & & & 3.0 \\
\hline & D3-4 & 0.6 & 0.05 & 0.05 & 0.5 & 35.0 & & & 5.25 \\
\hline \multirow{7}{*}{ D4 } & D4-1 & 0.7 & $0.1-$ & -0.1 & 0.2 & 9.5 & \multirow{7}{*}{3.103} & \multirow{7}{*}{9.1} & 0.854 \\
\hline & D4-2 & 0.5 & -0.5 & 0.8 & 0.3 & 14.2 & & & 1.281 \\
\hline & D4-3 & -0.1 & 0.1 & 0.02 & 0.01 & 1.1 & & & 0.100 \\
\hline & D4-4 & 0.1 & 0.7 & 1.2 & 0.7 & 33.0 & & & 3.002 \\
\hline & D4-5 & 0.2 & 1.3 & 0.3 & 0.6 & 28.4 & & & 2.573 \\
\hline & D4-6 & 0.5 & -0.02 & -0.02 & 0.1 & 4.8 & & & 0.436 \\
\hline & D4-7 & -0.2 & 0.2 & 0.2 & 0.2 & 9.5 & & & 0.854 \\
\hline \multirow{5}{*}{ D5 } & D5-1 & 1.0 & -0.1 & 2.1 & 3.0 & 40.5 & \multirow{5}{*}{5.704} & \multirow{5}{*}{16.8} & 6.603 \\
\hline & D5-2 & -0.8 & -0.9 & 0.2 & -1.5 & 7.7 & & & 1.083 \\
\hline & D5-3 & 0.4 & -0.2 & 2.0 & 2.2 & 29.7 & & & 4.790 \\
\hline & D5-4 & $\begin{array}{l}-0.2 \\
\end{array}$ & 1.2 & 0.5 & 1.5 & 20.2 & & & 3.193 \\
\hline & D5-5 & 0.2 & 0.2 & 0.2 & 0.2 & 10.9 & & & 1.631 \\
\hline \multirow{6}{*}{ D6 } & D6-1 & -0.3 & 0.25 & 0.3 & 0.25 & 4.00 & \multirow{6}{*}{6.073} & \multirow{6}{*}{17.9} & 0.716 \\
\hline & D6-2 & 0.1 & -0.25 & 0.6 & 0.45 & 8.00 & & & 1.432 \\
\hline & D6-3 & 1.5 & 0.125 & 2.00 & 3.6 & 42.0 & & & 7.519 \\
\hline & D6-4 & 0.3 & 0.5 & 0.5 & 1.3 & 20.0 & & & 3.58 \\
\hline & D6-5 & -1.75 & -0.4 & 1.5 & -0.35 & 2.00 & & & 0.358 \\
\hline & D6-6 & 0.3 & 0.125 & 2.00 & 2.4 & 24.0 & & & 4.297 \\
\hline \multirow{5}{*}{ D7 } & D7-1 & & & & & 27.0 & & & 3.591 \\
\hline & D7-2 & & & & & 25.0 & & & 3.325 \\
\hline & D7-3 & & & & & 20.0 & 4.500 & 13.3 & 2.66 \\
\hline & D7-4 & & & & & 13.0 & & & 1.729 \\
\hline & D7-5 & & & & & 15.0 & & & 1.995 \\
\hline & & & Total & & & & 33.972 & & 0 \\
\hline
\end{tabular}




\section{Hesham T. Eissa and Ahmed N. A. El-Nahas "A Proposed Model for Measuring the Performance of Smart Cities in Egypt"}

\section{Proposed Model for Measuring the Performance of Smart Communities / Cities in Egypt}

The Model Architecture (The Absent Dimension):

The model was based on a set of dimensions derived from global frameworks with the addition to new dimensions as a result of studying the gap between what exists and what is proposed to emphasize the dimensions of civilization, cultural and social identity as well as the mental and visual image and economic base ... etc. According to the characteristics of each sub-dimension, indicators have been identified.

As for the relative quantitative weights of the indicators, a mathematical method was followed to determine the frequency of the main and sub dimensions, after adding the absent/new dimensions into two groups of cities, with a total number of 10 cities. The frequency averages were updated for the first group of 7 cities after adding the civilization and urban identity dimension and the relative weights of the main dimensions were extracted. The frequency averages were also updated for the second group of 3 cities after adding the new sub-dimensions to determine the frequency ratio for each sub-dimension within its group to the dimension. Then Adding up all those frequencies and considering them $100 \%$ for the group and for all groups and thus calculate the relative weight of each sub-dimension, following the same means, divides it evenly among the indicators of each sub-dimension to calculate the relative weight of each indicator as shown in Table (5).

\subsection{Proposed Model}

The proposed model consists of 7 main dimensions, 34 sub-dimensions, and 93 indicators as indicated in Table (6) by which the performance of smart cities can be measured in addition to measuring the performance of cities wishing to convert to smart cities as well. This measuring method would be done periodically to evaluate how the city developing its performance.

Table (6)- The proposed model for measuring the performance of smart communities/cities

\begin{tabular}{|c|c|c|c|c|c|c|c|}
\hline \multicolumn{8}{|c|}{ Proposed Assessment Model for the Performance of SMART Communities / Cities } \\
\hline 参 & Sub-Dimensions & Characteristics & $\begin{array}{l}\text { Key Performance } \\
\text { Indicators (KPIs) }\end{array}$ & 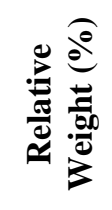 & 苞 & 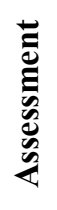 & $\stackrel{\bar{\pi}}{\stackrel{5}{\theta}}$ \\
\hline \multirow{8}{*}{ 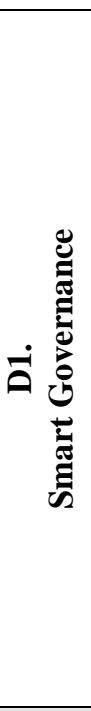 } & \multirow{3}{*}{$\begin{array}{l}\text { D1-1. } \quad \mathbf{7 . 0 5 0 \%} \\
\text { Participation in } \\
\text { public life }\end{array}$} & The rate of participation & $\begin{array}{l}\text { City representatives in } \\
\text { relation to the population }\end{array}$ & 2.35 & & & \multirow{3}{*}{7.050} \\
\hline & & The rate of participation & $\begin{array}{c}\text { Political activities for } \\
\text { individuals }\end{array}$ & 2.35 & & & \\
\hline & & Type of participation & $\begin{array}{l}\text { The importance of } \\
\text { politics for individuals }\end{array}$ & 2.35 & & & \\
\hline & \multirow{3}{*}{$\begin{array}{c}\text { D1-2. } 2.115 \% \\
\text { and social Public } \\
\text { services }\end{array}$} & Spending rate & $\begin{array}{l}\text { Municipal spending in } \\
\text { relation to the population }\end{array}$ & 0.705 & & & \multirow{3}{*}{2.115} \\
\hline & & Childhood representation & $\begin{array}{l}\text { Children's participation } \\
\text { in care centers }\end{array}$ & 0.705 & & & \\
\hline & & $\begin{array}{c}\text { Quality satisfaction } \\
\text { measurement for } \\
\text { education }\end{array}$ & $\begin{array}{c}\text { Individual satisfaction } \\
\text { with the quality of } \\
\text { schools }\end{array}$ & 0.705 & & & \\
\hline & \multirow{2}{*}{$\begin{array}{c}\text { D1-3. } \quad \mathbf{4 . 9 3 5 \%} \\
\text { Transparent } \\
\text { governance }\end{array}$} & Equal opportunity & $\begin{array}{l}\text { Satisfaction with } \\
\text { transparency }\end{array}$ & 2.4675 & & & \multirow{2}{*}{4.935} \\
\hline & & Accountability & $\begin{array}{c}\text { Consensus on fighting } \\
\text { corruption }\end{array}$ & 2.4675 & & & \\
\hline \multicolumn{4}{|c|}{ Total of the dimension } & & & & 14.1 \\
\hline
\end{tabular}




\section{Hesham T. Eissa and Ahmed N. A. El-Nahas "A Proposed Model for Measuring the Performance of Smart Cities in Egypt"}

Table (6) (Continued) -model for measuring the performance of smart communities / cities The proposed

\begin{tabular}{|c|c|c|c|c|c|c|c|}
\hline 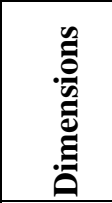 & Sub-Dimensions & Characteristics & $\begin{array}{l}\text { Key Performance } \\
\text { Indicators (KPIs) }\end{array}$ & 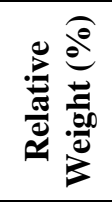 & 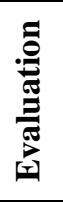 & 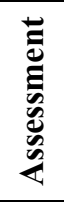 & $\stackrel{\bar{\Xi}}{0}$ \\
\hline \multirow{9}{*}{ i } & \multirow{3}{*}{$\begin{array}{cr}\text { D2-1 } & \mathbf{3 . 1 7 4 \%} \\
\text { Local accessibility }\end{array}$} & $\begin{array}{c}\text { Public transportation } \\
\text { availability }\end{array}$ & $\begin{array}{c}\text { Public transport network } \\
\text { in relation to the number } \\
\text { of individuals }\end{array}$ & 1.058 & & & \multirow{3}{*}{3.174} \\
\hline & & Access to public transport & $\begin{array}{c}\text { Individual satisfaction } \\
\text { with ease of access }\end{array}$ & 1.058 & & & \\
\hline & & $\begin{array}{l}\text { Public transportation } \\
\text { efficiency }\end{array}$ & $\begin{array}{c}\text { Individuals' satisfaction } \\
\text { with the quality of public } \\
\text { transportation }\end{array}$ & 1.058 & & & \\
\hline & $\begin{array}{c}\text { D2-2. } \mathbf{4 . 2 7 8 \%} \\
\text { International } \\
\text { accessibility } \\
\end{array}$ & International mobility & Global accessibility & 4.278 & & & 4.278 \\
\hline & \multirow{2}{*}{$\begin{array}{l}\text { D2-3. } \quad \mathbf{3 . 1 7 4 \%} \\
\text { Availability of IT- } \\
\text { Infrastructure }\end{array}$} & $\begin{array}{c}\text { Home communication } \\
\text { capabilities }\end{array}$ & $\begin{array}{c}\text { Availability of computers } \\
\text { at homes }\end{array}$ & 1.587 & & & \multirow[b]{2}{*}{3.174} \\
\hline & & Internet service & $\begin{array}{c}\text { Availability of } \\
\text { broadband internet in } \\
\text { homes }\end{array}$ & 1.587 & & & \\
\hline & \multirow{3}{*}{$\begin{array}{l}\text { D2-4. } \quad \mathbf{3 . 1 7 4 \%} \\
\text { Sustainability of the } \\
\text { transport system }\end{array}$} & $\begin{array}{c}\text { The Preservation of the } \\
\text { environment }\end{array}$ & Transport sharing & 1.058 & & & \multirow{3}{*}{3.174} \\
\hline & & Safety and Security & traffic Safety & 1.058 & & & \\
\hline & & Economic mobility & Use economical cars & 1.058 & & & \\
\hline \multicolumn{4}{|c|}{ Total of the dimension } & & & & 13.8 \\
\hline \multirow{9}{*}{ ช } & \multirow{2}{*}{$\begin{array}{c}\text { D3-1. } 1.5 \% \\
\text { Environmental } \\
\text { conditions }\end{array}$} & Clean energy sources & Sunrise hours & 0.75 & & & \multirow{2}{*}{1.5} \\
\hline & & & $\begin{array}{c}\text { Availability of green } \\
\text { areas }\end{array}$ & 0.75 & & & \\
\hline & \multirow{3}{*}{$\begin{array}{c}\text { D3-2. } \quad \mathbf{5 . 2 5 \%} \\
\text { Air quality } \\
\text { (no pollution) }\end{array}$} & Air pollution & Summer smog & 1.75 & & & \multirow{3}{*}{5.25} \\
\hline & & Environmental Pollution & $\begin{array}{c}\text { A specific environmental } \\
\text { problem }\end{array}$ & 1.75 & & & \\
\hline & & Public Health & $\begin{array}{l}\text { Respiratory diseases / } \\
\text { number of individuals }\end{array}$ & 1.75 & & & \\
\hline & \multirow{2}{*}{$\begin{array}{c}\text { D3-3. } \mathbf{3 . 0 \%} \\
\text { Ecological } \\
\text { awareness }\end{array}$} & $\begin{array}{c}\text { Awareness of } \\
\text { environmental protection }\end{array}$ & $\begin{array}{l}\text { Individual efforts to } \\
\text { protect the environment }\end{array}$ & 1.5 & & & \multirow{2}{*}{3.0} \\
\hline & & $\begin{array}{c}\text { Awareness of } \\
\text { environmental protection }\end{array}$ & $\begin{array}{l}\text { Opinion on the subject of } \\
\text { environmental protection }\end{array}$ & 1.5 & & & \\
\hline & \multirow{2}{*}{$\begin{array}{c}\text { D3-4. } \\
\text { Sustainable resource } \\
\text { management }\end{array}$} & Water waste & $\begin{array}{l}\text { Effective water } \\
\text { consumption / use } \\
\text { In relation to GDP }\end{array}$ & 2.625 & & & \multirow[t]{2}{*}{5.25} \\
\hline & & Waste of energy & $\begin{array}{c}\text { Electricity consumption / } \\
\text { usage relative to GDP }\end{array}$ & 2.625 & & & \\
\hline \multicolumn{5}{|c|}{ Total of the dimension } & & & 15.0 \\
\hline \multirow{3}{*}{ 苔莣 } & \multirow{3}{*}{$\begin{array}{cc}\text { D4-1. } & \mathbf{0 . 8 5 4 \%} \\
\text { Cultural facilities }\end{array}$} & Entertainment & $\begin{array}{c}\text { Cinema visit rate per } \\
\text { person }\end{array}$ & 0.284 & & & \multirow{3}{*}{0.854} \\
\hline & & Education & $\begin{array}{c}\text { Museum visit rate per } \\
\text { person }\end{array}$ & 0.285 & & & \\
\hline & & Entertainment & $\begin{array}{c}\text { Theater visit rate per } \\
\text { person }\end{array}$ & 0.285 & & & \\
\hline
\end{tabular}


Table (6) (Continued) -proposed model for measuring the performance of smart communities / cities The

\begin{tabular}{|c|c|c|c|c|c|c|c|}
\hline 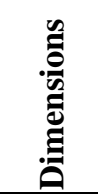 & Sub-Dimensions & Characteristics & $\begin{array}{l}\text { Key Performance } \\
\text { Indicators (KPIs) }\end{array}$ & 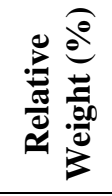 & 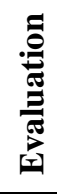 & 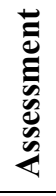 & 吾 \\
\hline \multirow{17}{*}{ 草 } & \multirow{4}{*}{$\begin{array}{l}\text { D4-2. } \mathbf{1 . 2 8 1 \%} \\
\text { Health conditions }\end{array}$} & Public health measurement & $\begin{array}{c}\text { Life rate / average age of } \\
\text { individuals }\end{array}$ & 0.321 & & & \multirow{4}{*}{1.281} \\
\hline & & $\begin{array}{c}\text { Material resources for } \\
\text { health }\end{array}$ & $\begin{array}{c}\text { Number of hospital beds } \\
\text { population / }\end{array}$ & 0.320 & & & \\
\hline & & $\begin{array}{c}\text { Human resources for } \\
\text { health }\end{array}$ & $\begin{array}{l}\text { The number of doctors in } \\
\text { population relation to the }\end{array}$ & 0.320 & & & \\
\hline & & Public health system & $\begin{array}{c}\text { Quality of the health } \\
\text { system }\end{array}$ & 0.320 & & & \\
\hline & \multirow{3}{*}{$\begin{array}{l}\text { D4-3. } \mathbf{0 . 1 0 0 \%} \\
\text { Personal Security }\end{array}$} & Security & Crime rate & 0.033 & & & \multirow{3}{*}{0.100} \\
\hline & & & Crime death rate & 0.033 & & & \\
\hline & & $\begin{array}{c}\text { Measuring security } \\
\text { efficiency }\end{array}$ & $\begin{array}{c}\text { Personal satisfaction with } \\
\text { personal security }\end{array}$ & 0.034 & & & \\
\hline & \multirow{3}{*}{$\begin{array}{l}\text { D4-4. } \mathbf{3 . 0 0 2 \%} \\
\text { Quality of housing }\end{array}$} & The right to housing & $\begin{array}{c}\text { Providing minimum } \\
\text { standards }\end{array}$ & 1.001 & & & \multirow{3}{*}{3.002} \\
\hline & & Per capita & $\begin{array}{c}\text { Area of populated area / } \\
\text { number of individuals }\end{array}$ & 1.001 & & & \\
\hline & & $\begin{array}{c}\text { Measuring housing } \\
\text { efficiency }\end{array}$ & $\begin{array}{l}\text { satisfaction Individual } \\
\text { with housing }\end{array}$ & 1.000 & & & \\
\hline & \multirow{3}{*}{$\begin{array}{lr}\text { D4-5. } & \mathbf{2 . 5 7 3 \%} \\
\text { Education facilities }\end{array}$} & & $\begin{array}{c}\text { The number of students } \\
\text { in relation to the number } \\
\text { of residents }\end{array}$ & 0.858 & & & \multirow{3}{*}{2.573} \\
\hline & & Teaching and learning & $\begin{array}{l}\text { Easy access to the } \\
\text { education system }\end{array}$ & 0.858 & & & \\
\hline & & & $\begin{array}{c}\text { Quality of the } \\
\text { educational system }\end{array}$ & 0.857 & & & \\
\hline & \multirow{2}{*}{$\begin{array}{l}\text { D4-6. } \quad \mathbf{0 . 4 3 6 \%} \\
\text { Touristic attraction }\end{array}$} & & $\begin{array}{c}\text { Importance as a tourist } \\
\text { site }\end{array}$ & 0.146 & & & \multirow[b]{2}{*}{0.436} \\
\hline & & Tourism development & $\begin{array}{c}\text { The number of annual } \\
\text { tourist stays in relation to } \\
\text { the population }\end{array}$ & 0.145 & & & \\
\hline & \multirow{2}{*}{$\begin{array}{l}\text { D4-7. } \mathbf{0 . 8 5 4 \%} \\
\text { Economic welfare }\end{array}$} & & $\begin{array}{c}\text { Realizing the seriousness } \\
\text { of poverty }\end{array}$ & 0.427 & & & \multirow[t]{2}{*}{0.854} \\
\hline & & Economic awareness & Poverty rate & 0.427 & & & \\
\hline \multicolumn{5}{|c|}{ Total of the dimension } & & & 9.1 \\
\hline \multirow{4}{*}{ 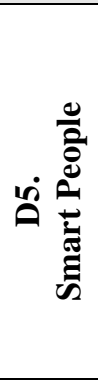 } & \multirow{4}{*}{$\begin{array}{c}\text { D5-1. } \quad \mathbf{6 . 6 0 3 \%} \\
\text { Qualification } \\
\text { Level }\end{array}$} & $\begin{array}{l}\text { Importance as a } \\
\text { knowledge center }\end{array}$ & $\begin{array}{l}\text { The best research centers } \\
\text { and universities }\end{array}$ & 1.651 & & & \multirow{4}{*}{6.603} \\
\hline & & \begin{tabular}{|c}
$\begin{array}{c}\text { International standard } \\
\text { classification of Education } \\
\text { (ISCED) }\end{array}$ \\
\end{tabular} & $\begin{array}{l}\text { The number of qualified } \\
\text { individuals at level 5-6 }\end{array}$ & 1.651 & & & \\
\hline & & $\begin{array}{c}\text { Stage }(1 \& 2) \text { of higher } \\
\text { education }\end{array}$ & $\begin{array}{c}\text { The number of members } \\
\text { of the two phases of the } \\
\text { population }\end{array}$ & 1.651 & & & \\
\hline & & Cognitive competence & language skills & 1.650 & & & \\
\hline
\end{tabular}


Table (6) (Continued) - The proposed model for measuring the performance of smart communities / cities

\begin{tabular}{|c|c|c|c|c|c|c|c|}
\hline 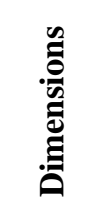 & Sub-Dimensions & Characteristics & $\begin{array}{l}\text { Key Performance } \\
\text { Indicators (KPIs) }\end{array}$ & 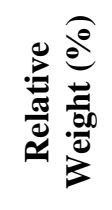 & 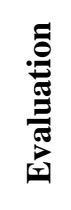 & 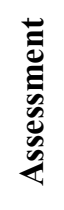 & $\stackrel{5}{0}$ \\
\hline \multirow{12}{*}{ 官 } & \multirow{3}{*}{$\begin{array}{cc}\text { D5-2. } & \mathbf{1 . 0 8 3 \%} \\
\text { Lifelong learning }\end{array}$} & Cognitive perception & $\begin{array}{c}\text { Borrowing books } \\
\text { according to the number } \\
\text { of individuals }\end{array}$ & 0.361 & & & \multirow{3}{*}{1.083} \\
\hline & & Continuous education & $\begin{array}{l}\text { Contribution to long- } \\
\text { term education }\end{array}$ & 0.361 & & & \\
\hline & & Cultural awareness & $\begin{array}{c}\text { Contribute to language } \\
\text { courses }\end{array}$ & 0.361 & & & \\
\hline & \multirow{3}{*}{$\begin{array}{cc}\text { D5-3. } & \mathbf{4 . 7 9 0 \%} \\
\text { Ethnic pluralism }\end{array}$} & & $\begin{array}{c}\text { Participation of } \\
\text { foreigners }\end{array}$ & 1.596 & & & \multirow{3}{*}{790.4} \\
\hline & & Citizenship & $\begin{array}{c}\text { Participation of citizens } \\
\text { residing abroad }\end{array}$ & 1.597 & & & \\
\hline & & & $\begin{array}{c}\text { Providing a climate } \\
\text { conductive to migration }\end{array}$ & 1.597 & & & \\
\hline & \multirow{4}{*}{$\begin{array}{c}\text { D5-4. } \mathbf{3 . 1 9 3 \%} \\
\text { Open } \\
\text { Mindedness }\end{array}$} & $\begin{array}{l}\text { The importance of } \\
\text { regional participation }\end{array}$ & $\begin{array}{c}\text { Turnout for regional } \\
\text { elections }\end{array}$ & 0.798 & & & \multirow{4}{*}{3.193} \\
\hline & & & $\begin{array}{l}\text { Information about } \\
\text { regional associations }\end{array}$ & 0.798 & & & \\
\hline & & & Getting a new job & 0.798 & & & \\
\hline & & Creativity & $\begin{array}{l}\text { Others participate in a } \\
\text { creative industry }\end{array}$ & 0.799 & & & \\
\hline & \multirow{2}{*}{$\begin{array}{c}\text { D5-5. } \mathbf{1 . 6 3 1 \%} \\
\text { Contribution to } \\
\text { public life }\end{array}$} & $\begin{array}{c}\text { The importance of local } \\
\text { participation }\end{array}$ & $\begin{array}{c}\text { Demand for civil } \\
\text { elections }\end{array}$ & 0.815 & & & \multirow[t]{2}{*}{1.631} \\
\hline & & Self-efforts & $\begin{array}{c}\text { Contributing to volunteer } \\
\text { work }\end{array}$ & 0.816 & & & \\
\hline \multirow{4}{*}{\multicolumn{2}{|c|}{$\begin{array}{c}\text { D6-1. } \quad \mathbf{0 . 7 1 6 \%} \\
\text { Innovative spirit }\end{array}$}} & Total of the dimensior & & & & & 16.8 \\
\hline & & $\begin{array}{c}\text { Total research and } \\
\text { development expenditures }\end{array}$ & Expenditures from GDP & 0.239 & & & \multirow{3}{*}{0.716} \\
\hline & & & $\begin{array}{l}\text { The employment rate in } \\
\text { the Knowledge-based } \\
\text { sectors }\end{array}$ & 0.239 & & & \\
\hline & & Patents & $\begin{array}{l}\text { Patent applications } \\
\text { relative to population }\end{array}$ & 0.238 & & & \\
\hline \multirow{6}{*}{ ڤั } & \multirow{2}{*}{$\begin{array}{cc}\text { D6-2. } & \mathbf{1 . 4 3 2} \% \\
\text { Entrepreneurship }\end{array}$} & & Self-employment rate & 0.716 & & & \multirow[b]{2}{*}{1.432} \\
\hline & & Create job opportunities & $\begin{array}{l}\text { Number of new } \\
\text { registered companies }\end{array}$ & 0.716 & & & \\
\hline & $\begin{array}{l}\text { D6-3. } \mathbf{7 . 5 1 9 \%} \\
\text { Economic image \& } \\
\text { trademarks } \\
\end{array}$ & Commercial licenses & $\begin{array}{c}\text { Decision-making centers } \\
\text { and brands }\end{array}$ & 7.519 & & & 7.519 \\
\hline & $\begin{array}{c}\text { D6-4. } \quad \mathbf{3 . 5 8 0 \%} \\
\text { Productivity }\end{array}$ & $\begin{array}{c}\text { The standard of living of } \\
\text { an individual }\end{array}$ & GDP per capita & 3.58 & & & 3.58 \\
\hline & D6-5. $\quad 0.358 \%$ & & Unemployment rate & 0.179 & & & \multirow[b]{2}{*}{0.358} \\
\hline & $\begin{array}{c}\text { Flexibility of labor } \\
\text { market }\end{array}$ & $\begin{array}{l}\text { Labor market } \\
\text { requirements }\end{array}$ & Partial employment rate & 0.179 & & & \\
\hline
\end{tabular}


Table (6) (Continued) - The proposed model for measuring the performance of smart communities / cities

\begin{tabular}{|c|c|c|c|c|c|c|c|}
\hline 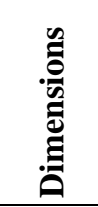 & Sub-Dimensions & Characteristics & $\begin{array}{l}\text { Key Performance } \\
\text { Indicators (KPIs) }\end{array}$ & 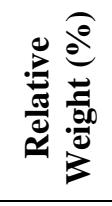 & 高 & 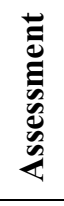 & $\stackrel{\frac{\pi}{0}}{\circ}$ \\
\hline \multirow{4}{*}{ 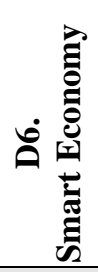 } & \multirow{4}{*}{$\begin{array}{c}\text { D6-6. } \quad \mathbf{4 . 2 9 7 \%} \\
\text { International } \\
\text { embeddedness }\end{array}$} & $\begin{array}{c}\text { Pushing toward } \\
\text { globalization }\end{array}$ & $\begin{array}{l}\text { The headquarters of } \\
\text { international companies }\end{array}$ & 1.075 & & & \multirow{4}{*}{4.297} \\
\hline & & The local stock market & Market Contribution & 1.074 & & & \\
\hline & & & $\begin{array}{c}\text { transportation for Air } \\
\text { passengers }\end{array}$ & 1.074 & & & \\
\hline & & & Goods' air transportation & 1.074 & & & \\
\hline \multicolumn{5}{|c|}{ Total of the dimension } & & & 17.9 \\
\hline \multirow{18}{*}{ 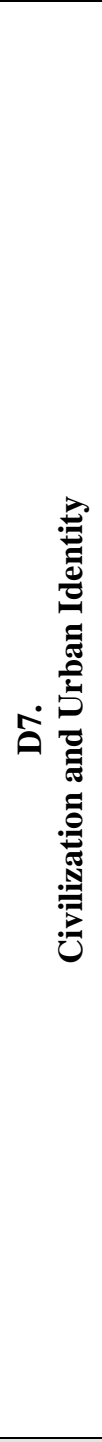 } & \multirow{3}{*}{$\begin{array}{c}\text { D7-1. } \mathbf{3 . 5 9 1 \%} \\
\text { Cultural Identity }\end{array}$} & Symbolism & $\begin{array}{c}\text { Historical / philosophical } \\
\text { / functional reference }\end{array}$ & 1.197 & & & \multirow{3}{*}{3.591} \\
\hline & & $\begin{array}{c}\text { Tie to intellectual } \\
\text { significance }\end{array}$ & $\begin{array}{r}\text { Political / religious / } \\
\text { social significance }\end{array}$ & 1.197 & & & \\
\hline & & $\begin{array}{c}\text { Development of the spirit } \\
\text { of national belonging }\end{array}$ & civilizational Trait & 1.197 & & & \\
\hline & \multirow{4}{*}{$\begin{array}{c}\text { D7-2. } \quad 3.325 \% \\
\text { Iconography }\end{array}$} & Formation & $\begin{array}{c}\text { Singularity / adding } \\
\text { personality / meaning } \\
\text { affirmation }\end{array}$ & 0.832 & & & \multirow{4}{*}{3.325} \\
\hline & & Amazingness & \begin{tabular}{|c|} 
Volumetric / \\
technological / strength / \\
control / glory
\end{tabular} & 0.831 & & & \\
\hline & & Urban context & $\begin{array}{c}\text { Harmony with the } \\
\text { surrounding environment }\end{array}$ & 0.831 & & & \\
\hline & & Economic return & $\begin{array}{c}\text { Attracting investment } \\
\text { (global / regional / local) }\end{array}$ & 0.831 & & & \\
\hline & \multirow{4}{*}{$\begin{array}{c}\text { D7-3. } \mathbf{2 . 6 6 \%} \\
\text { Mental Image }\end{array}$} & & Landmarks & 0.665 & & & \multirow{4}{*}{2.66} \\
\hline & & Visual structure elements & $\begin{array}{c}\text { Visual sequences and } \\
\text { tracks }\end{array}$ & 0.665 & & & \\
\hline & & & Squares and visual nodes & 0.665 & & & \\
\hline & & & $\begin{array}{c}\text { Neighborhoods, borders } \\
\text { and landscape }\end{array}$ & 0.665 & & & \\
\hline & \multirow{3}{*}{$\begin{array}{c}\text { D7-4. } \mathbf{1 . 7 2 9 \%} \\
\text { Zero Carbon }\end{array}$} & Energy consumption & $\begin{array}{l}\text { Reduction of energy } \\
\text { consumption }\end{array}$ & 0.577 & & & \multirow{3}{*}{1.729} \\
\hline & & Land use & $\begin{array}{c}\text { Standard ratios (zero } \\
\text { (carbon }\end{array}$ & 0.576 & & & \\
\hline & & $\begin{array}{r}\text { Environmental } \\
\text { sustainability } \\
\end{array}$ & \begin{tabular}{|r|} 
Technologies, materials, \\
and operating systems
\end{tabular} & 0.576 & & & \\
\hline & \multirow{4}{*}{$\begin{array}{c}\text { D7-5. } \mathbf{1 . 9 9 5 \%} \\
\text { Strategic Plan }\end{array}$} & Site & \begin{tabular}{|c|} 
access / Ease of \\
availability of resources \\
\end{tabular} & 0.499 & & & \multirow{4}{*}{1.995} \\
\hline & & The influence & $\begin{array}{c}\text { Global / regional / local } \\
\text { level }\end{array}$ & 0.499 & & & \\
\hline & & The economic base & Renewable growth poles & 0.499 & & & \\
\hline & & The possibility of growth & $\begin{array}{l}\text { Growth opportunities } \\
\text { (horizontal / vertical) }\end{array}$ & 0.498 & & & \\
\hline \multicolumn{5}{|c|}{ the dimension Total of } & & & 13.3 \\
\hline \multicolumn{5}{|c|}{ TOTAL } & & & 100.00 \\
\hline
\end{tabular}


7. Measuring the Performance of Smart Cities

Locally (New Administrative Capital)

7.1. Reasons for choosing the New Administrative Capital for performance evaluation as a smart city The administrative capital is considered, :First in the world in terms thaccording to designers, the 12 of intelligence [25]; which makes it not only in the ranks of smart cities, but in the forefront in those cities as it includes a group of high technologies :epresented inr

- Unified digital infrastructure.

- A smart utility network.

- Sensors and smart sensors (surveillance cameras smart parking spaces - smart lighting systems)

- The Security Authority Center, which is affiliated with the Ministry of Interior.

- The city's administration and operation center, which belongs to the company responsible for the administration of the capital.

The city was designed according to seven :Second basic principles that confirm its design concept as a are ummarized as smart city. These principles :follows

a) The city is designed to exceed a 15 :A green city per capita share of green areas and open ${ }^{2} \mathrm{~m}$ spaces, which is higher than the world standard .average

b) Use all the determinants and :A sustainable city standards of sustainability such as energy generation from renewable sources and waste .recycling

c) Allocating $40 \%$ of the road :A pedestrian city network for pedestrians and bicycles in order to in the same encourage people to exercise and .time reducing car exhaust

d) The housing :A city of habitation and life represents only $30 \%$ of the city area, and the city was divided into three regions according to the :following densities
- of high density housing $\% 35$

- $\quad$ singaverage density hou $\% 50$

- low density housing \%15

e) The city is planned with a :A connected city progressive and diversified road network of smart transportation and includes all means of transportation such as train, tram, metro, .microbus and taxi

f) esigned with the aim The city was $d$ :A smart city of becoming one of the most intelligent cities in the world; it contains all available digital technology that would be provided to the population, as well as all electronic methods of .dealing with the public or monitoring systems

g) It includes an international :business city The center for finance and business that includes the .Greater Cairo sector and the Suez Canal region Therefore, the New Administrative Capital in Egypt is one of the cities that possess the components of societies/cities, as well as the first Egyptian smart experience, that makes it a good candidate to be chosen to validate the capability of the proposed .model in measuring the performance of smart cities

Measuring the performance of the New $\mathbf{. 7 . 2}$ :Capital as a smart city Administrative

The proposed model was applied to the administrative capital to test the capability of the model and to evaluate the Egyptian experience in establishing smart cities/communities according to from global the dimensions and indicators extracted the measurement result was (4) ureFig models 'after adding new dimensions and indicators $\$ \% 63.51$ the measurement result was ‘(5) ureFig ،(Table (7 and this confirms the correspondence of the $6 \% 73.45$ models. measurement result with global and regional That confirms and maximizes the benefits of using the new model to measure the performance of smart cities at all global, regional and local levels. Also the ability of using it to evaluate and measure the ave been performance of traditional cities those $h$ .transformed to smart cities or wish to do so

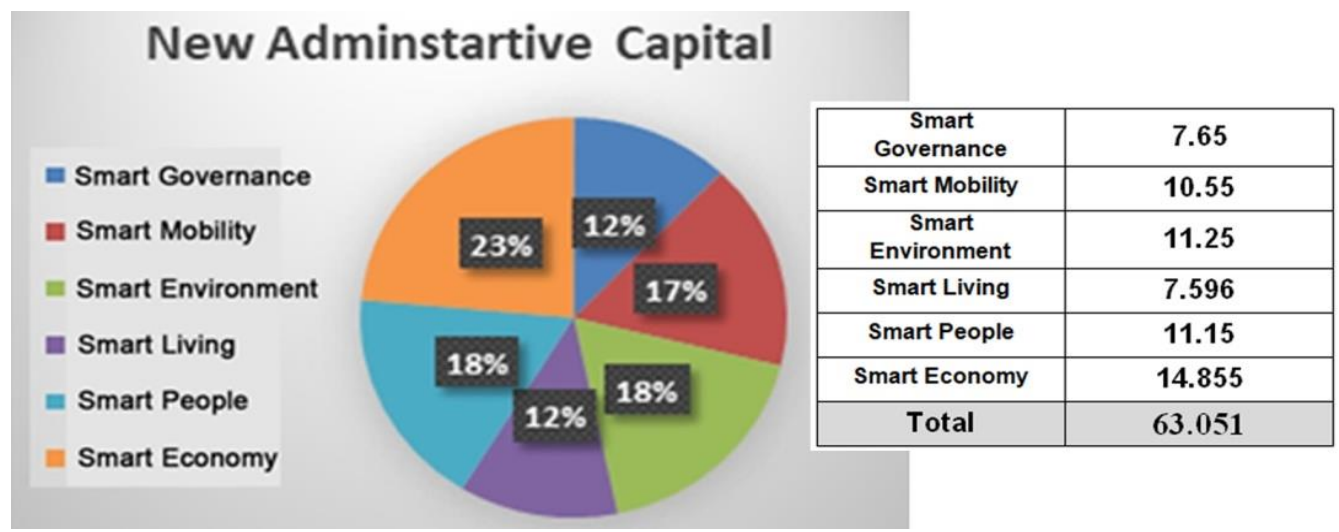

Figure (4) - Evaluating the New Administrative Capital according to the dimensions from international models 


\section{Hesham T. Eissa and Ahmed N. A. El-Nahas "A Proposed Model for Measuring the Performance of Smart Cities in Egypt"}

Table (7) - Evaluation of the performance of the New Administrative Capital in Cairo (after adding new dimension indicators)

\begin{tabular}{|c|c|c|c|c|c|c|c|}
\hline \multicolumn{8}{|c|}{ Proposed Assessment Model for the Performance of SMART Communities / Cities } \\
\hline 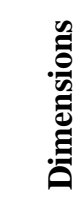 & Sub-Dimensions & Characteristics & $\begin{array}{l}\text { Key Performance } \\
\text { Indicators (KPIs) }\end{array}$ & 产 & 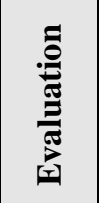 & 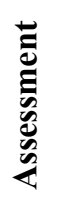 & 氶 \\
\hline \multirow{8}{*}{ 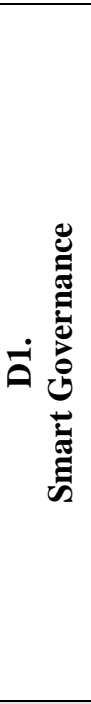 } & \multirow{3}{*}{$\begin{array}{l}\text { D1-1. } \quad \mathbf{7 . 0 5 0 \%} \\
\text { Participation in } \\
\text { public life }\end{array}$} & The rate of participation & $\begin{array}{l}\text { City representatives in } \\
\text { relation to the population }\end{array}$ & 2.35 & 1.5 & & \multirow{3}{*}{7.050} \\
\hline & & participation The rate of & $\begin{array}{c}\text { Political activities for } \\
\text { individuals }\end{array}$ & 2.35 & 1 & & \\
\hline & & Type of participation & $\begin{array}{l}\text { The importance of } \\
\text { politics for individuals }\end{array}$ & 2.35 & 1.5 & & \\
\hline & \multirow{3}{*}{$\begin{array}{c}\text { D1-2. } \quad \mathbf{2 . 1 1 5 \%} \\
\text { Public and social } \\
\text { services }\end{array}$} & Spending rate & $\begin{array}{l}\text { Municipal spending in } \\
\text { relation to the population }\end{array}$ & 0.705 & 0.6 & & \multirow{3}{*}{2.115} \\
\hline & & Childhood representation & $\begin{array}{c}\text { Children's participation in } \\
\text { care centers }\end{array}$ & 0.705 & 0.6 & & \\
\hline & & $\begin{array}{l}\text { Quality satisfaction } \\
\text { measurement for } \\
\text { education }\end{array}$ & $\begin{array}{c}\text { Individual satisfaction } \\
\text { with the quality of } \\
\text { schools }\end{array}$ & 0.705 & 0.5 & & \\
\hline & \multirow{2}{*}{$\begin{array}{l}\text { D1-3. } \quad \mathbf{4 . 9 3 5 \%} \\
\text { Transparent } \\
\text { governance }\end{array}$} & opportunity Equal & $\begin{array}{l}\text { Satisfaction with } \\
\text { transparency }\end{array}$ & 2.4675 & 0.75 & & \multirow{2}{*}{4.935} \\
\hline & & Accountability & $\begin{array}{c}\text { Consensus on fighting } \\
\text { corruption }\end{array}$ & 2.4675 & 1.2 & & \\
\hline \multicolumn{4}{|c|}{ Total of the dimension } & & 7.65 & & 14.1 \\
\hline \multirow{9}{*}{ ) } & \multirow{3}{*}{$\begin{array}{cr}\text { D2-1 } & \mathbf{3 . 1 7 4 \%} \\
\text { Local accessibility }\end{array}$} & $\begin{array}{l}\text { Public transportation } \\
\text { availability }\end{array}$ & $\begin{array}{c}\text { Public transport network } \\
\text { in relation to the number } \\
\text { of individuals }\end{array}$ & 1.058 & 0.8 & & \multirow{3}{*}{3.174} \\
\hline & & Access to public transport & $\begin{array}{c}\text { Individual satisfaction } \\
\text { with ease of access }\end{array}$ & 1.058 & 0.8 & & \\
\hline & & $\begin{array}{l}\text { Public transportation } \\
\text { efficiency }\end{array}$ & $\begin{array}{l}\text { Individuals' satisfaction } \\
\text { quality of public with the } \\
\text { transportation }\end{array}$ & 1.058 & 0.8 & & \\
\hline & $\begin{array}{c}\text { D2-2. } \mathbf{4 . 2 7 8 \%} \\
\text { International } \\
\text { accessibility }\end{array}$ & International mobility & Global accessibility & 4.278 & 4 & & 4.278 \\
\hline & \multirow{2}{*}{$\begin{array}{c}\text { D2-3. } \quad \mathbf{3 . 1 7 4 \%} \\
\text { Availability of IT- } \\
\text { Infrastructure }\end{array}$} & $\begin{array}{l}\text { Home communication } \\
\text { capabilities }\end{array}$ & $\begin{array}{c}\text { Availability of computers } \\
\text { at homes }\end{array}$ & 1.587 & 1.3 & & \multirow{2}{*}{3.174} \\
\hline & & Internet service & $\begin{array}{c}\text { Availability of broadband } \\
\text { internet in homes }\end{array}$ & 1.587 & 1 & & \\
\hline & \multirow{3}{*}{$\begin{array}{l}\text { D2-4. } \mathbf{3 . 1 7 4 \%} \\
\text { Sustainability of the } \\
\text { transport system }\end{array}$} & $\begin{array}{c}\text { The Preservation of the } \\
\text { environment }\end{array}$ & Transport sharing & 1.058 & 0.9 & & \multirow{3}{*}{3.174} \\
\hline & & Safety and Security & traffic Safety & 1.058 & 0.75 & & \\
\hline & & Economic mobility & Use economical cars & 1.058 & 0.2 & & \\
\hline \multicolumn{4}{|c|}{ Total of the dimension } & & 10.55 & & 13.8 \\
\hline
\end{tabular}


Table (7) continued - Evaluation of the performance of the New Administrative Capital in Cairo

(after adding new dimension indicators)

\begin{tabular}{|c|c|c|c|c|c|c|c|}
\hline 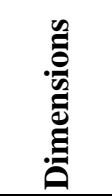 & Sub-Dimensions & Characteristics & $\begin{array}{l}\text { Key Performance } \\
\text { Indicators (KPIs) }\end{array}$ & 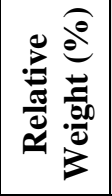 & 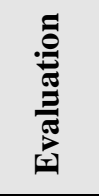 & 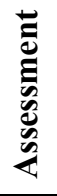 & $\stackrel{\frac{5}{0}}{\stackrel{\theta}{\theta}}$ \\
\hline \multirow{9}{*}{ คి } & \multirow{2}{*}{$\begin{array}{c}\text { D3-1. } 1.5 \% \\
\text { Environmental } \\
\text { conditions }\end{array}$} & Clean energy sources & Sunrise hours & 0.75 & 0.65 & & \multirow{2}{*}{1.5} \\
\hline & & & $\begin{array}{c}\text { Availability of green } \\
\text { areas }\end{array}$ & 0.75 & 0.7 & & \\
\hline & \multirow{3}{*}{$\begin{array}{c}\text { D3-2. } \quad \mathbf{5 . 2 5 \%} \\
\text { Air quality } \\
\text { (no pollution) }\end{array}$} & Air pollution & Summer smog & 1.75 & 1.45 & & \multirow{3}{*}{5.25} \\
\hline & & Environmental Pollution & $\begin{array}{c}\text { A specific environmental } \\
\text { problem }\end{array}$ & 1.75 & 1.6 & & \\
\hline & & Public Health & $\begin{array}{l}\text { Respiratory diseases / } \\
\text { number of individuals }\end{array}$ & 1.75 & 1.6 & & \\
\hline & \multirow{2}{*}{$\begin{array}{cc}\text { D3-3. } & \mathbf{3 . 0 \%} \\
\text { Ecological awareness }\end{array}$} & $\begin{array}{c}\text { Awareness of } \\
\text { environmental protection }\end{array}$ & $\begin{array}{l}\text { Individual efforts to } \\
\text { protect the environment }\end{array}$ & 1.5 & 1 & & \multirow{2}{*}{3.0} \\
\hline & & $\begin{array}{c}\text { Awareness of } \\
\text { environmental protection }\end{array}$ & $\begin{array}{l}\text { Opinion on the subject of } \\
\text { environmental protection }\end{array}$ & 1.5 & 1 & & \\
\hline & \multirow{2}{*}{$\begin{array}{c}\text { D3-4. } \quad \mathbf{5 . 2 5 \%} \\
\text { Sustainable resource } \\
\text { management }\end{array}$} & Water waste & $\begin{array}{l}\text { Effective water } \\
\text { consumption / use } \\
\text { In relation to GDP }\end{array}$ & 2.625 & 1.5 & & \multirow[t]{2}{*}{5.25} \\
\hline & & Waste of energy & $\begin{array}{c}\text { Electricity consumption / } \\
\text { usage relative to GDP }\end{array}$ & 2.625 & 1.75 & & \\
\hline \multicolumn{5}{|c|}{ Total of the dimension } & 11.25 & & 15.0 \\
\hline \multirow{13}{*}{ 芒泀 } & \multirow{3}{*}{$\begin{array}{c}\text { D\%49.854 } \\
\text { Cultural facilities }\end{array}$} & Entertainment & $\begin{array}{c}\text { Cinema visit rate per } \\
\text { person }\end{array}$ & 0.284 & 0.26 & & \multirow{3}{*}{0.854} \\
\hline & & Education & $\begin{array}{c}\text { Museum visit rate per } \\
\text { person }\end{array}$ & 0.285 & 0.26 & & \\
\hline & & Entertainment & $\begin{array}{c}\text { Theater visit rate per } \\
\text { person }\end{array}$ & 0.285 & 0.26 & & \\
\hline & \multirow{4}{*}{$\begin{array}{c}\text { D4-2. } \mathbf{1 . 2 8 1 \%} \\
\text { Health conditions }\end{array}$} & Public health measurement & $\begin{array}{c}\text { Life rate / average age of } \\
\text { individuals }\end{array}$ & 0.321 & 0.3 & & \multirow{4}{*}{1.281} \\
\hline & & $\begin{array}{c}\text { Material resources for } \\
\text { health }\end{array}$ & $\begin{array}{c}\text { Number of hospital beds } \\
\text { population / }\end{array}$ & 0.320 & 0.3 & & \\
\hline & & Human resources for health & $\begin{array}{l}\text { The number of doctors in } \\
\text { relation to the population }\end{array}$ & 0.320 & 0.3 & & \\
\hline & & Public health system & $\begin{array}{c}\text { Quality of the health } \\
\text { system }\end{array}$ & 0.320 & 0.25 & & \\
\hline & \multirow{3}{*}{$\begin{array}{cc}\text { D4-3. } & \mathbf{0 . 1 0 0 \%} \\
\text { Personal Security }\end{array}$} & Security & Crime rate & 0.033 & 0.03 & & \multirow{3}{*}{0.100} \\
\hline & & & rate Crime death & 0.033 & 0.03 & & \\
\hline & & $\begin{array}{c}\text { Measuring security } \\
\text { efficiency }\end{array}$ & $\begin{array}{l}\text { Personal satisfaction } \\
\text { with personal security }\end{array}$ & 0.034 & 0.02 & & \\
\hline & \multirow{3}{*}{$\begin{array}{l}\text { D4-4. } \quad \mathbf{3 . 0 0 2 \%} \\
\text { Quality of housing }\end{array}$} & The right to housing & $\begin{array}{l}\text { Providing minimum } \\
\text { standards }\end{array}$ & 1.001 & 0.9 & & \multirow{3}{*}{3.002} \\
\hline & & Per capita & $\begin{array}{l}\text { / Area of populated area } \\
\text { number of individuals }\end{array}$ & 1.001 & 1 & & \\
\hline & & $\begin{array}{c}\text { Measuring housing } \\
\text { efficiency }\end{array}$ & $\begin{array}{c}\text { Individual satisfaction } \\
\text { with housing }\end{array}$ & 1.000 & 0.7 & & \\
\hline
\end{tabular}




\section{Hesham T. Eissa and Ahmed N. A. El-Nahas "A Proposed Model for Measuring the Performance of Smart Cities in Egypt”}

Table (7) continued - Evaluation of the performance of the New Administrative Capital in Cairo

(after adding new dimension indicators)

\begin{tabular}{|c|c|c|c|c|c|c|c|}
\hline .气̃ & Sub-Dimensions & Characteristics & $\begin{array}{l}\text { Key Performance } \\
\text { Indicators (KPIs) }\end{array}$ & 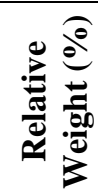 & 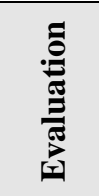 & 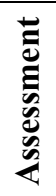 & $\stackrel{5}{\stackrel{5}{0}}$ \\
\hline \multirow{7}{*}{ 它 } & \multirow{3}{*}{$\begin{array}{lr}\text { D4-5. } & \mathbf{2 . 5 7 3 \%} \\
\text { Education facilities }\end{array}$} & & $\begin{array}{l}\text { The number of students } \\
\text { in relation to the number } \\
\text { of residents }\end{array}$ & 0.858 & 0.7 & & \multirow{3}{*}{2.573} \\
\hline & & Teaching and learning & $\begin{array}{l}\text { Easy access to the } \\
\text { education system }\end{array}$ & 0.858 & 0.65 & & \\
\hline & & & $\begin{array}{c}\text { Quality of the } \\
\text { educational system }\end{array}$ & 0.857 & 0.6 & & \\
\hline & \multirow[b]{2}{*}{$\begin{array}{l}\text { D4-6. } \quad \mathbf{0 . 4 3 6 \%} \\
\text { Touristic attraction }\end{array}$} & & $\begin{array}{c}\text { Importance as a tourist } \\
\text { site }\end{array}$ & 0.146 & 0.086 & & \multirow[b]{2}{*}{0.436} \\
\hline & & Tourism development & $\begin{array}{c}\text { number of annual The } \\
\text { tourist stays in relation to } \\
\text { the population }\end{array}$ & 0.145 & 0.15 & & \\
\hline & \multirow{2}{*}{$\begin{array}{cc}\text { D4-7. } & \mathbf{0 . 8 5 4 \%} \\
\text { Economic } & \text { welfare }\end{array}$} & & $\begin{array}{c}\text { Realizing the seriousness } \\
\text { of poverty }\end{array}$ & 0.427 & 0.4 & & \multirow[t]{2}{*}{0.854} \\
\hline & & Economic awareness & Poverty rate & 0.427 & 0.4 & & \\
\hline \multicolumn{5}{|c|}{ Total of the dimension } & 7.596 & & 9.1 \\
\hline \multirow{14}{*}{ 官 } & \multirow{4}{*}{ 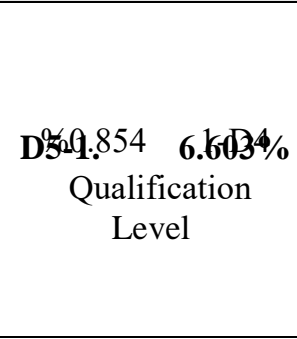 } & $\begin{array}{c}\text { Importance as a knowledge } \\
\text { center }\end{array}$ & $\begin{array}{c}\text { The best research centers } \\
\text { and universities }\end{array}$ & 1.651 & 0.9 & & \multirow{4}{*}{6.603} \\
\hline & & $\begin{array}{c}\text { International standard } \\
\text { classification of Education }\end{array}$ & $\begin{array}{l}\text { The number of qualified } \\
\text { individuals at level 5-6 }\end{array}$ & 1.651 & 0.65 & & \\
\hline & & $\begin{array}{c}\text { Stage }(1 \& 2) \text { of higher } \\
\text { education }\end{array}$ & $\begin{array}{l}\text { The number of members } \\
\text { of the two phases of the } \\
\text { population }\end{array}$ & 1.651 & 1.4 & & \\
\hline & & Cognitive competence & language skills & 1.650 & 1.2 & & \\
\hline & \multirow{3}{*}{$\begin{array}{cc}\text { D5-2. } & \mathbf{1 . 0 8 3 \%} \\
\text { Lifelong learning }\end{array}$} & perception Cognitive & $\begin{array}{c}\text { Borrowing books } \\
\text { according to the number } \\
\text { of individuals }\end{array}$ & 0.361 & 0.2 & & \multirow{3}{*}{1.083} \\
\hline & & Continuous education & $\begin{array}{l}\text { Contribution to long- } \\
\text { term education }\end{array}$ & 0.361 & 0.15 & & \\
\hline & & Cultural awareness & $\begin{array}{c}\text { Contribute to language } \\
\text { courses }\end{array}$ & 0.361 & 0.2 & & \\
\hline & \multirow{3}{*}{$\begin{array}{cc}\text { D5-3. } & \mathbf{4 . 7 9 0 \%} \\
\text { Ethnic pluralism }\end{array}$} & & $\begin{array}{l}\text { Participation of } \\
\text { foreigners }\end{array}$ & 1.596 & 1.25 & & \multirow{3}{*}{790.4} \\
\hline & & Citizenship & $\begin{array}{c}\text { Participation of citizens } \\
\text { residing abroad }\end{array}$ & 1.597 & 1.25 & & \\
\hline & & & $\begin{array}{l}\text { Providing a climate } \\
\text { conductive to migration }\end{array}$ & 1.597 & 1.2 & & \\
\hline & \multirow{4}{*}{$\begin{array}{c}\text { D5-4. } \mathbf{3 . 1 9 3 \%} \\
\text { Open } \\
\text { Mindedness }\end{array}$} & $\begin{array}{c}\text { The importance of regional } \\
\text { participation }\end{array}$ & $\begin{array}{c}\text { Turnout for regional } \\
\text { elections }\end{array}$ & 0.798 & 0.3 & & \multirow{4}{*}{3.193} \\
\hline & & & $\begin{array}{l}\text { Information about } \\
\text { regional associations }\end{array}$ & 0.798 & 0.3 & & \\
\hline & & & Getting a new job & 0.798 & 0.6 & & \\
\hline & & Creativity & $\begin{array}{l}\text { Others participate in a } \\
\text { creative industry }\end{array}$ & 0.799 & 0.4 & & \\
\hline
\end{tabular}




\section{Hesham T. Eissa and Ahmed N. A. El-Nahas "A Proposed Model for Measuring the Performance of Smart Cities in Egypt”}

Table (7) continued - Evaluation of the performance of the New Administrative Capital in Cairo

(after adding new dimension indicators)

\begin{tabular}{|c|c|c|c|c|c|c|c|}
\hline 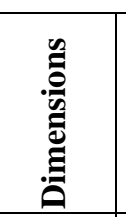 & Sub-Dimensions & Characteristics & $\begin{array}{l}\text { Key Performance } \\
\text { Indicators (KPIs) }\end{array}$ & 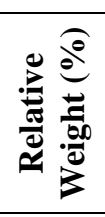 & 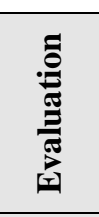 & 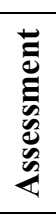 & $\stackrel{5}{\frac{\pi}{6}}$ \\
\hline \multirow{2}{*}{ 的言苛 } & \multirow{2}{*}{$\begin{array}{c}\text { D5-5. } \mathbf{1 . 6 3 1 \%} \\
\text { Contribution to } \\
\text { public life }\end{array}$} & $\begin{array}{c}\text { The importance of local } \\
\text { participation }\end{array}$ & $\begin{array}{c}\text { Demand for civil } \\
\text { elections }\end{array}$ & 0.815 & 0.4 & & \multirow[t]{2}{*}{1.631} \\
\hline & & Self-efforts & $\begin{array}{l}\text { Contributing to } \\
\text { volunteer work }\end{array}$ & 0.816 & 0.75 & & \\
\hline \multicolumn{5}{|c|}{ Total of the dimension } & 11.15 & & 16.8 \\
\hline \multirow{13}{*}{ 气ั } & \multirow{3}{*}{$\begin{array}{c}\text { D6-1. } \mathbf{0 . 7 1 6 \%} \\
\text { Innovative spirit }\end{array}$} & $\begin{array}{c}\text { Total research and } \\
\text { development expenditures }\end{array}$ & Expenditures from GDP & 0.239 & 0.05 & & \multirow{3}{*}{0.716} \\
\hline & & & $\begin{array}{c}\text { The employment rate in } \\
\text { the Knowledge-based } \\
\text { sectors }\end{array}$ & 0.239 & 0.17 & & \\
\hline & & Patents & $\begin{array}{l}\text { Patent applications } \\
\text { relative to population }\end{array}$ & 0.238 & 0.085 & & \\
\hline & \multirow[b]{2}{*}{$\begin{array}{cc}\text { D6-2. } & \mathbf{1 . 4 3 2} \% \\
\text { Entrepreneurship }\end{array}$} & & Self-employment rate & 0.716 & 0.65 & & \multirow[b]{2}{*}{1.432} \\
\hline & & Create job opportunities & $\begin{array}{l}\text { Number of new } \\
\text { registered companies }\end{array}$ & 0.716 & 0.5 & & \\
\hline & $\begin{array}{c}\text { D6-3. } \\
\text { Economic image \& } \\
\text { trademarks }\end{array}$ & Commercial licenses & $\begin{array}{l}\text { Decision-making centers } \\
\text { and brands }\end{array}$ & 7.519 & 6.5 & & 7.519 \\
\hline & $\begin{array}{c}\text { D6-4. } \mathbf{3 . 5 8 0 \%} \\
\text { Productivity }\end{array}$ & $\begin{array}{c}\text { The standard of living of } \\
\text { an individual }\end{array}$ & GDP per capita & 3.58 & 2.7 & & 3.58 \\
\hline & \multirow{2}{*}{$\begin{array}{c}\text { D6-5. } \quad \mathbf{0 . 3 5 8 \%} \\
\text { Flexibility of labor } \\
\text { market }\end{array}$} & & Unemployment rate & 0.179 & 0.1 & & \multirow[b]{2}{*}{0.358} \\
\hline & & $\begin{array}{c}\text { market Labor } \\
\text { requirements }\end{array}$ & Partial employment rate & 0.179 & 0.1 & & \\
\hline & \multirow{4}{*}{$\begin{array}{c}\text { D6-6. } \quad \mathbf{4 . 2 9 7 \%} \\
\text { International } \\
\text { embeddedness }\end{array}$} & $\begin{array}{c}\text { Pushing toward } \\
\text { globalization }\end{array}$ & $\begin{array}{l}\text { The headquarters of } \\
\text { international companies }\end{array}$ & 1.075 & 1 & & \multirow{4}{*}{4.297} \\
\hline & & The local stock market & Market Contribution & 1.074 & 1 & & \\
\hline & & & Passengers' air transport & 1.074 & 1 & & \\
\hline & & & Goods' air transport & 1.074 & 1 & & \\
\hline \multicolumn{5}{|c|}{ Total of the dimension } & 14.85 & & 17.9 \\
\hline \multirow{7}{*}{ 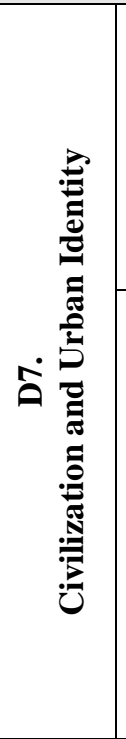 } & \multirow{3}{*}{$\begin{array}{c}\text { D7-1. } \quad \mathbf{3 . 5 9 1 \%} \\
\text { Cultural Identity }\end{array}$} & Symbolism & $\begin{array}{c}\text { Historical / } \\
\text { philosophical/ } \\
\text { functional reference }\end{array}$ & 1.197 & 0.7 & & \multirow{3}{*}{3.591} \\
\hline & & $\begin{array}{c}\text { Tie to intellectual } \\
\text { significance }\end{array}$ & $\begin{array}{c}\text { Political / religious / } \\
\text { social significance }\end{array}$ & 1.197 & 1.1 & & \\
\hline & & $\begin{array}{c}\text { Development of the spirit } \\
\text { of national belonging }\end{array}$ & civilizational Trait & 1.197 & 1.1 & & \\
\hline & \multirow{4}{*}{$\begin{array}{c}\text { D7-2. } \quad \mathbf{3 . 3 2 5 \%} \\
\text { Iconography }\end{array}$} & Formation & $\begin{array}{c}\text { Singularity / adding } \\
\text { personality / meaning } \\
\text { affirmation }\end{array}$ & 0.832 & 0.4 & & \multirow{4}{*}{3.325} \\
\hline & & Amazingness & \begin{tabular}{|c|}
$\begin{array}{c}\text { Volumetric / } \\
\text { technological / strength / } \\
\text { control / glory }\end{array}$ \\
\end{tabular} & 0.831 & 0.65 & & \\
\hline & & Urban context & $\begin{array}{l}\text { Harmony with the } \\
\text { surrounding } \\
\text { environment }\end{array}$ & 0.831 & 0.65 & & \\
\hline & & Economic return & $\begin{array}{c}\text { Attracting investment } \\
\text { (regional / local / global) }\end{array}$ & 0.831 & 0.7 & & \\
\hline
\end{tabular}


Table (7) continued - Evaluation of the performance of the New Administrative Capital in Cairo (after adding new dimension indicators)

\begin{tabular}{|c|c|c|c|c|c|c|c|}
\hline 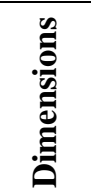 & Sub-Dimensions & Characteristics & $\begin{array}{l}\text { Key Performance } \\
\text { Indicators (KPIs) }\end{array}$ & 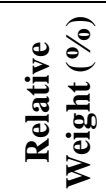 & 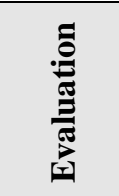 & 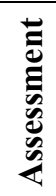 & $\stackrel{5}{0}$ \\
\hline \multirow{11}{*}{ 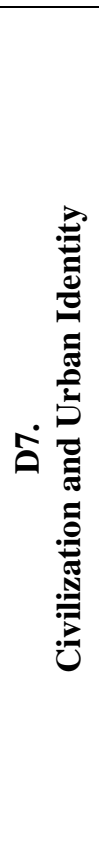 } & \multirow{4}{*}{$\begin{array}{c}\text { D7-3. } \mathbf{2 . 6 6 \%} \\
\text { Mental Image }\end{array}$} & & Landmarks & 0.665 & 0.6 & & \multirow{4}{*}{2.66} \\
\hline & & Visual structure elements & $\begin{array}{c}\text { Visual sequences and } \\
\text { tracks }\end{array}$ & 0.665 & 0.6 & & \\
\hline & & & $\begin{array}{c}\text { Squares and visual } \\
\text { nodes }\end{array}$ & 0.665 & 0.6 & & \\
\hline & & & $\begin{array}{c}\text { Neighborhoods, borders } \\
\text { and landscape }\end{array}$ & 0.665 & 0.6 & & \\
\hline & \multirow{3}{*}{$\begin{array}{c}\text { D7-4. } \mathbf{1 . 7 2 9 \%} \\
\text { Zero Carbon }\end{array}$} & Energy consumption & $\begin{array}{c}\text { Reduction of energy } \\
\text { consumption }\end{array}$ & 0.577 & 0.4 & & \multirow{3}{*}{1.729} \\
\hline & & Land use & $\begin{array}{c}\text { Standard ratios (zero } \\
\text { (carbon }\end{array}$ & 0.576 & 0.35 & & \\
\hline & & $\begin{array}{r}\text { Environmental } \\
\text { sustainability }\end{array}$ & $\begin{array}{c}\text { materials, 'Technologies } \\
\text { and operating systems }\end{array}$ & 0.576 & 0.35 & & \\
\hline & \multirow{4}{*}{$\begin{array}{c}\text { D7-5. } \quad \mathbf{1 . 9 9 5 \%} \\
\text { Strategic Plan }\end{array}$} & Site & $\begin{array}{c}\text { Ease of access / } \\
\text { availability of resources }\end{array}$ & 0.499 & 0.45 & & \multirow{4}{*}{1.995} \\
\hline & & The influence & $\begin{array}{c}\text { Global / regional / local } \\
\text { level }\end{array}$ & 0.499 & 0.35 & & \\
\hline & & The economic base & $\begin{array}{l}\text { Renewable growth } \\
\text { poles }\end{array}$ & 0.499 & 0.35 & & \\
\hline & & The possibility of growth & $\begin{array}{l}\text { Growth opportunities } \\
\text { (horizontal / vertical) }\end{array}$ & 0.498 & 0.45 & & \\
\hline \multicolumn{5}{|c|}{ Total of the dimension } & 10.4 & & 13.3 \\
\hline \multicolumn{5}{|c|}{ TOTAL } & 73.451 & & 100.00 \\
\hline
\end{tabular}

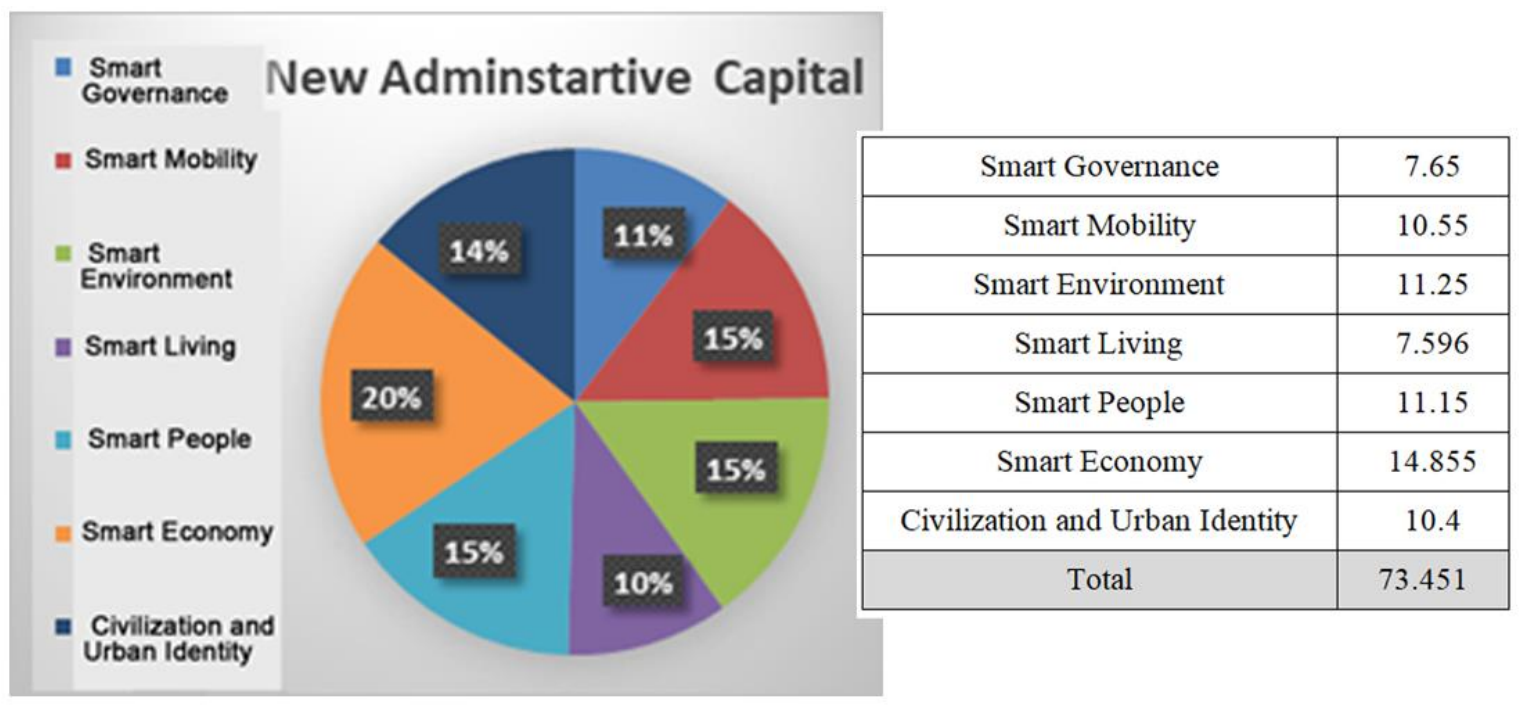

Figure (5) - Evaluating the New Administrative Capital after adding the missing dimensions. 


\section{Hesham T. Eissa and Ahmed N. A. El-Nahas "A Proposed Model for Measuring the Performance of Smart Cities in Egypt”}

\section{Conclusions}

Smart cities are expected to form a better future for the world especially regarding environmental issues; therefore continues assessment for such cities performance will help developing the whole approach in an efficient way. Hence, the study ew dimensions added to what has been identified $n$ extracted from the dimensions of global frameworks to measure the performance of smart cities. Correspondingly, proposed a new model as a new approach (2020) to measure the performance of smart 1 can be used, as well, by cities. The proposed mode traditional city administrations looking for switching into smart cities on annual basis. In addition to that the proposed model helping to determine the progress of cities towards smart and can be used to assess the of cities and rank them among the cities performance .of the world

\section{References}

[1] Albert S., Flournoy D., LeBrasseur R., "Networked communities: strategies for digital collaboration, Information Science Reference", Hershey, New York, 2009

[2] Canadian Federal Government (2002), Fostering innovation and use. Industry Canada, http://broadband.gc.ca/Broadband-

document/english/chapter5.htm (retrieved July 20, 2002).

[3] California Institute for Smart Communities (San Diego), "Ten Steps to Becoming a Smart Community", SDSU International Center for Communications, April 30, 2001

[4] Doran, George T. "There's a S.M.A.R.T. way to write management's goals and objectives." Management Review 70.11 (Nov. 1981): 35. Business Source Corporate EBSCO, 15 Oct. 2008.)

[5] Bogue, R. "Use S.M.A.R.T. Goals to Launch Management by Objectives Plan", TechRepublic, (2013). http://www.techrepublic.com/article/use-smartgoals-to-launch-management-by-objectives-plan/ (Accessed: August, 2020)

[6] Zhiyuan Fang, "E-Government in Digital Era: Concept, Practice, and Development", International Journal of The Computer, The Internet and Management, Vol. 10, No.2, (2002), P1-22

[7] European Commission, 2013, EIP SCC, European Innovation Partnership on Smart Cities and Communities, Strategic Implementation Plan, $\quad 14.10 . \quad$ (2013). http://ec.europa.eu/eip/smartcities (Accessed: January 2020)

[8] DOE, 2010, Department of Energy, United States of America, "Data access of privacy issues related to smart grid technologies", October 5, (2010).

https://www.energy.gov/sites/prod/files/gcprod/d ocuments/Broadband_Report_Data_Privacy_10_ 5.pdf (Accessed: June 2020)

[9] Stratigea, A., "The concept of 'smart cities' Towards community development?", Networks and Communication Studies (NETCOM), p. 375-388, 26-3/4 (2012)

[10] John G. Jung, "Every Intelligent Community is a Smart City, but...", May 27th, (2016). https://www.intelligentcommunity.org/every_int elligent_community_is_a_smart_city_but (Accessed: August 2020)

[11] Airaksinen M., Ahvenniemi H. and Virtanen M., "Smart City Key Performance Indicators", European Energy Research Alliance, EERA, Join Program Energy in Cities status Report (2012)

[12] Hiremath, R. B., Balachandra, P., Kumar, B., Bansode, S. S. and Murali, J., 2013, "Indicatorbased urban sustainability - A review". Energy for Sustainable Development, V17-6, P555-563 (2013)

[13] McManus, P., "Measuring Urban Sustainability: the potential and pitfalls of city rankings", Australian Geographer, Vol. 43, No. 4, pp. 411424, (2012)

[14] Nielsen, P. S., Ben Amer, S., \& Halsnæs, K. "Definition of Smart Energy City and State of the art of 6 Transform cities using Key Performance Indicators: Deliverable 1.2.”, TRANSFORM-project, Technical University of Denmark, DTU, (2013)

[15] www.citykeys-project.eu (Official site)

[16] ISO 9000:2005, Quality management systems Fundamentals and vocabulary, https://www.iso.org/standard/42180.html (Accessed: March 2020)

[17] Dameri, R. P., "Searching for Smart City definition: a comprehensive proposal", International Journal of Computers \& Technology, 11(5), 2544-2551 (2013) Google Scholar

[18] ISO/TR 12773-1:2009, Business requirements for health summary records - Part 1: Requirements,

https://www.iso.org/standard/51683.html (Accessed: March 2020)

[19] OECD Green Growth Studies, "Green Growth in Cities", OECD Publishing, Paris, (2013) http://dx.doi.org/10.1787/9789264195325-en

(Accessed: August 2020) 
[20] Jubert, F. et al., "La e-administration", Levier de la réforme de l'état, Dunod, p25 (2005)

[21] Alawadhi, S., et al.: "Building understanding of smart city initiatives", 11th International Conference on Electronic Government (EGOV), Sep (2012), Kristiansand, Norway. pp.40-53 https://hal.inria.fr/hal-01543596/document (Accessed: June 2020)

[22]Dameri, R. P., "Defining an evaluation framework for digital city implementation", IEEE International Conference on Information Society, London (2012) Google Scholar
[23] OECD Guide to Measuring the Information Society 2011, OECD Publishing (2011) https://ec.europa.eu/eurostat/cache/metadata/Ann exes/isoc_se_esms_an2.pdf (Accessed: August 2020)

[24]Giffinger, R., "Smart cities - Ranking of European medium-sized cities", Centre of Regional Science, Vienna UT, October 2007, http://www.smart-

cities.eu/download/smart_cities_final_report.pdf, Retrieved 2009-11-11.

[25] http://acud.eg/ (Official site) 